\title{
Enzyme immobilization by adsorption: a review
}

\author{
Teofil Jesionowski $\cdot$ Jakub Zdarta $\cdot$ \\ Barbara Krajewska
}

Received: 21 January 2014/Revised: 14 May 2014/ Accepted: 18 June 2014/Published online: 27 June 2014

(C) The Author(s) 2014. This article is published with open access at Springerlink.com

\begin{abstract}
Endowed with unparalleled high catalytic activity and selectivity, enzymes offer enormous potential as catalysts in practical applications. These applications, however, are seriously hampered by enzymes' low thermal and chemical stabilities. One way to improve these stabilities is the enzyme immobilization. Among various tested methods of this process that make use of different enzyme-carrier interactions, immobilization by adsorption on solid carriers has appeared most common. According to these findings, in this review we present a comparative analysis of the literature reports on the recent trends in the immobilization of the enzymes by adsorption. This thorough study was prepared in order to provide a deeper understanding of the process. Both carriers, carrier modifiers and procedures developed for effective adsorption of the enzymes are discussed. The review may thus be helpful in choosing the right adsorption scheme for a given enzyme to achieve the improvement of its stability and activity for a specific application.
\end{abstract}

Keywords Enzymes immobilization - Adsorption · Carriers $\cdot$ Surface modifying agents $\cdot$ Applications

T. Jesionowski $(\bowtie) \cdot$ J. Zdarta

Faculty of Chemical Technology, Institute of Chemical

Technology and Engineering, Poznan University of Technology,

M. Skłodowskiej-Curie 2, 60965 Poznań, Poland

e-mail: teofil.jesionowski@put.poznan.pl

B. Krajewska

Faculty of Chemistry, Jagiellonian University, Ingardena 3, 30060 Kraków, Poland

\section{General overview}

Low thermal stability, narrow $\mathrm{pH}$ range, effective activity in water environment and the loss of catalytic activity after one cycle have been the greatest obstacles in the use of the enzymes in the multiple practical processes (Liese and Hilterhaus 2013; Gray et al. 2013; DiCosimo et al. 2013). However, the enormous catalytic potential offered by the enzymes for innumerable transformations, has stimulated intense studies aimed at the improvement of their properties (Mateo et al. 2007; Brady and Jordon 2009; FernandezLafuente 2009; Garcia-Galan et al. 2011; Cowan and Fernandez-Lafuente 2011; Rodrigues et al. 2013). Among several methods of this improvement that have been proposed, an immobilization of the enzymes is apparently most widely applied (Zhao 2010; Rodrigues et al. 2011; Hanefeld et al. 2013). The term first appeared in the literature at the beginning of twentieth century and referred to the enzymes bound directly to the carriers. At present this term has been extended to include both direct immobilizations on the carriers and the immobilizations supported with the intermediate agents (Cao et al. 2003; Hanefeld et al. 2009).

An immobilization of the enzymes on the solid carriers can be achieved using a broad variety of chemical and physical methods (Cao 2005; Sheldon 2007; Sheldon and van Pelt 2013). Among many methods proposed for the protein immobilization, the most important and useful is the immobilization by adsorption. Adsorption makes use of the physical interactions generated between the carrier and enzyme that include van der Waals forces, ionic interactions and hydrogen bonding. The binding are rather weak and, what is important, typically are does not change the native structure of the enzyme. This prevents the active sites of the enzyme from disturbing and allows the enzyme 


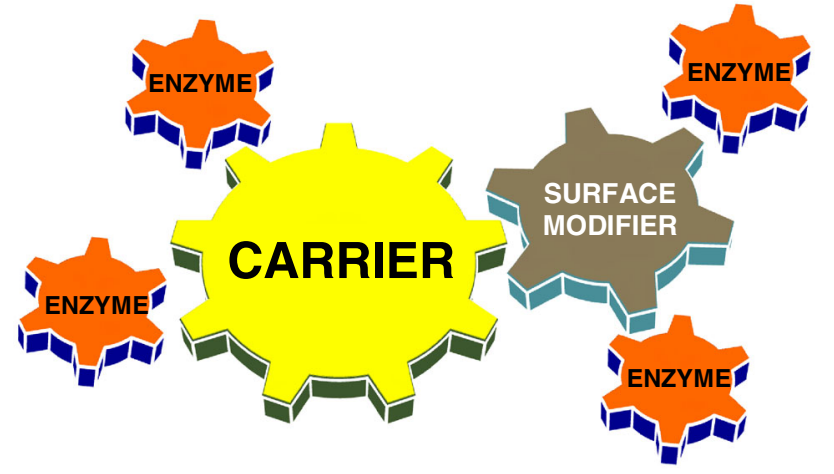

Fig. 1 Enzyme immobilization by adsorption

to retain its activity (Hernandez and Fernandez-Lafuente 2011; Hwang and Gu 2013). Notably, any carrier can be applied for enzyme adsorption, but not every enzyme can be immobilized on all carriers. The reason is that for the successful adsorption of the enzyme to occur, some certain conditions must be met, among which an enzyme-carrier affinity is most important. This is assured by the presence of the specific active groups on the carrier, which enable the generation of the enzyme-carrier interactions. However, if absent, the interactions can be tuned by applying intermediate agents (carrier modifiers) (Fig. 1).

A wide range of available compounds can be successfully used as the enzyme carriers. The criteria of the choice suitable for a given enzyme and its application include: the cost, availability, stability (or reactivity if necessary) in specific conditions, and the type of reactor. The physicochemical parameters of the carrier that should be taken into an account are: the surface area, particle size, pore structure and type of functional groups present on the surface. A general classification of typical carriers used for the enzyme adsorption is presented in Fig. 2.

In general, the carriers used for the enzyme immobilization by adsorption can be divided into both organic and inorganic origin. The most common inorganic carriers are silicas, titania and hydroxyapatite. The organic carriers by contrast, include compounds of natural origin, such as chitin, chitosan, cellulose and alginate, also the synthetic compounds, mainly polymers. The advantage of these matrices is that they can be readily chemically modified to match conditions for a given enzyme and its application.

Another important advantage of the enzyme immobilization is that the immobilized enzymes may show properties that can be exploited in the reactions performed in non-aqueous environments. Typically, the native enzymes are catalytically active in the aqueous media and they lose the activity in organic solvents. However, when immobilized, the enzymes may have their catalytic properties altered in a manner permitting them to preserve their activities in conditions other than aqueous. This is important for two reasons. One is that such enzymes can be used for the transformations of hydrophobic substrates that can only be performed in organic solvents (Carrea and Riva 2000; Klibanov 2001; Iyer and Ananthanarayan 2008). The other one is that the immobilized enzymes may exhibit catalytic properties in organic solvents different from those in aqueous environments. This can be exploited in guiding the reactions toward the desired products. Excellent examples of such properties are lipases and esterases; in aqueous environments those enzymes catalyze the hydrolysis of esters to alcohols, while in organic solvents they catalyze transesterifications of the same substrates (Klibanov 2001). Additionally, along with the use of the specific organic solvents, the following properties can be achieved:
Fig. 2 Carriers used for enzyme immobilization by adsorption

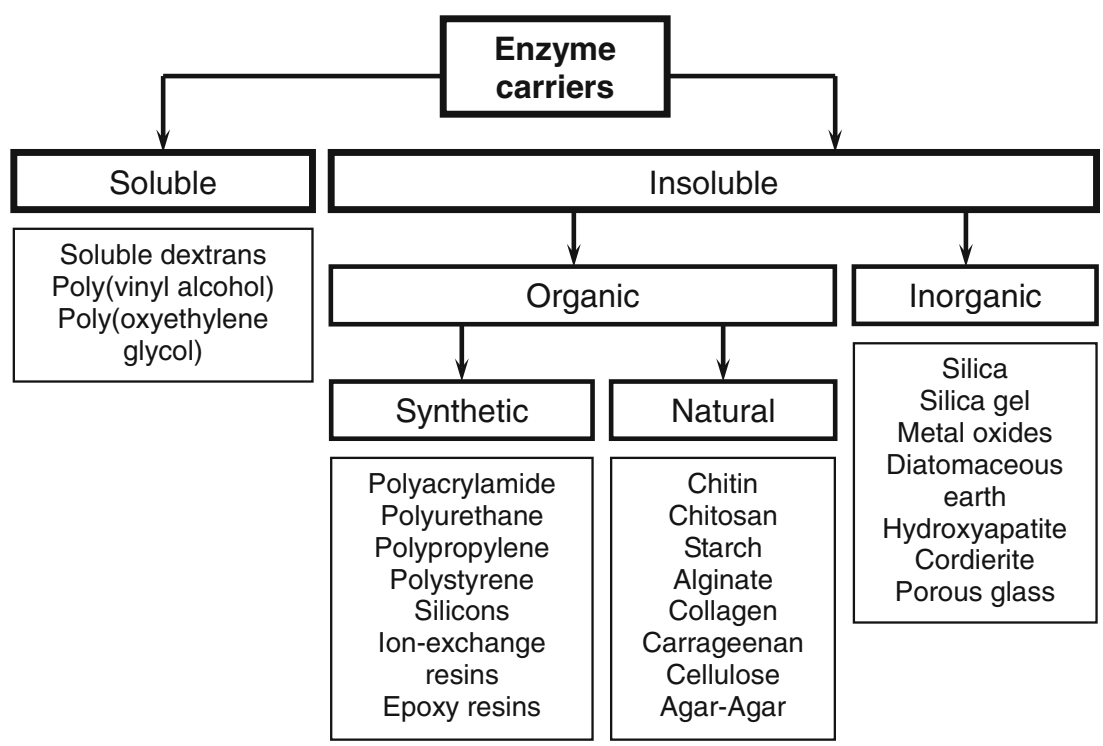


chemo-, regio- and enantioselectivity of the enzymes after immobilization may be customized for a specific purpose (Carrea and Riva 2000; Klibanov 2001), the reactions can be reversed, their yield may be increased, and also the homogeneous product may be obtained rather than a mixture of isomers or enantiomers. Importantly, it should not be overlooked that the water, present in an organic solvent, even in trace amounts, may significantly alter the parameters of the preparation obtained and may even affect the course of the entire process. Interestingly, organic solvents also affect the stabilities of the immobilized enzymes. This is because the enzymes desorb from the carriers to the organic solvents less readily than to the aqueous solutions.

Given the growing importance of immobilized enzymes as well as the complexity of their preparation, this review presents a thorough study on literature dealing with the immobilization of the enzymes by adsorption. Carriers utilized for the immobilization with and without the intermediate agents are reviewed, methods of adsorption on different types of the carriers are compared, and examples of the immobilized enzymes employed as catalysts in practical applications both in aqueous and non-aqueous (organic solvents, surfactants, ionic liquids) media are discussed. The data taken from the literature are presented as a summary in Table 1 and discussed individually in the subsequent sections: Carriers in Sect. 2, Surface modifiers in Sect. 3, and Properties of immobilized enzymes in Sect. 4.

\section{Carriers used for immobilization of enzymes by adsorption}

\subsection{Inorganic carriers}

Among many inorganic carriers used for immobilization of enzymes by adsorption, silicas are apparently those carriers, which have drawn most attention (Erhardt and Jordening 2007; Magner 2013; Hartmann and Kostrov 2013). Silicas of different dispersive-morphological parameters and porous structures have been proposed. A representative silica used for the enzyme immobilization on a large scale is mesoporous silica SBA-15 (Santa Barbara Amorphous) with hexagonal array of pores (Salis et al. 2010; Thorn et al. 2011). It is characterized by small pores, from 5 to about $30 \mathrm{~nm}$ in diameter and a hexagonal array of pores (Grudzień et al., 2006; 2007; Hartmann and Kostrov 2013). Large volume of mesopores, close to $1.0 \mathrm{~cm}^{3} / \mathrm{g}$ and $\mathrm{mi}-$ cropores of about $0.8 \mathrm{~cm}^{3} / \mathrm{g}$, and also a very well developed surface area from 500 to $1400 \mathrm{~m}^{2} / \mathrm{g}$ [Hartmann and Kostrov 2013] make this silica an excellent support for the enzyme immobilization. Another mesoporous silica MSU$\mathrm{H}$ (Yu and Fang 2013) has the specific surface area reaching $750 \mathrm{~m}^{2} / \mathrm{g}$, pore radius from 7 to $10 \mathrm{~nm}$ and pore volume from 0.9 to $1.0 \mathrm{~cm}^{3} / \mathrm{g}$. By contrast, in mesoporous silica MCM-41 (Mobil Composition of Matter), with hexagonally ordered mesopores (Choma et al. 2004; Weber et al. 2010), the pore size is from 2 to $8 \mathrm{~nm}$, which is controlled by adjusting the synthesis conditions and/or by applying surfactants with different chain lengths (pore sizes 2-5 nm) or expanders (pore sizes up to $8 \mathrm{~nm}$ ) in their preparation. The pore volume in this silica is close to $1.0 \mathrm{~cm}^{3} / \mathrm{g}$ and its surface area exceeds $1,200 \mathrm{~m}^{2} / \mathrm{g}$ (Magner 2013), which are features that classify this material as a carrier for the enzyme immobilization. FDU-12 (Fudan University Material) (Hartono et al. 2010) is another mesoporous silica material with face-centered cubic structures of spherical mesopores and surface area of about $700 \mathrm{~m}^{2} / \mathrm{g}$, pore size from 10 to $15 \mathrm{~nm}$ and pore volume from 0.6 to $0.7 \mathrm{~cm}^{3} / \mathrm{g}$. This silica and other silica matrices (Falahti et al. 2012) differing in pore size and structure, are also excellent carriers for enzyme immobilization. Likewise, highly ordered mesoporous silicas with $2 \mathrm{D}$ and $3 \mathrm{D}$ structures and mesopores from 2 to about $30 \mathrm{~nm}$, obtained by a surfactant and block copolymer templating, can be readily applied. The material of $3 \mathrm{D}$ structure is a better adsorbent and permits immobilization of a greater amount of the enzyme. The small particle of mesoporous silica (Chang et al. 2011) was reported to have a surface area of $820 \mathrm{~m}^{2} / \mathrm{g}$ and a pore diameter varying from 2 to $5 \mathrm{~nm}$, while the diameter of particles was close to $150 \mathrm{~nm}$. This small particle mesoporous silica was compared with the large particle mesoporous silica (Chang et al. 2011), which surface area was near $260 \mathrm{~m}^{2} / \mathrm{g}$, pore diameter varied from 20 to $40 \mathrm{~nm}$ and particle size reached $600 \mathrm{~nm}$. It was found that the larger surface area and smaller particle diameter favoured an immobilization of a greater amount of the enzymes. Cubic Ia3d mesoporous silica nanoparticles (Falahati et al. 2011) have the surface area of over $820 \mathrm{~m}^{2} /$ $\mathrm{g}$, pore diameters of about $7 \mathrm{~nm}$ and pore volume greater than $1.5 \mathrm{~cm}^{3} / \mathrm{g}$. To increase the surface area of the carrier available to the enzyme, the folded sheet mesoporous silica was proposed (Nara et al. 2010). Such a configuration permits an immobilization of the greater amounts of the enzymes at only insubstantial growth of cost of the carrier production. Silicas of smaller surface areas obtained mainly in the processes of hydrolysis and condensation of tetraalkoxysilanes (Grabicka and Jaroniec 2010; Fornera and Bauer 2012; Zheng et al. 2012) were also used for the enzyme immobilization.

Other silica carriers widely used for the enzyme adsorption are silica gels (Bhattacharyya et al. 2010; Lee et al. 2010). They have very well developed porous structures and surface areas, as well as high mechanical strength and thermal stability. The size of silica gel particles varies from 70 to $150 \mu \mathrm{m}$ depending on the type and the pore size reaches $250 \mathrm{~nm}$. 







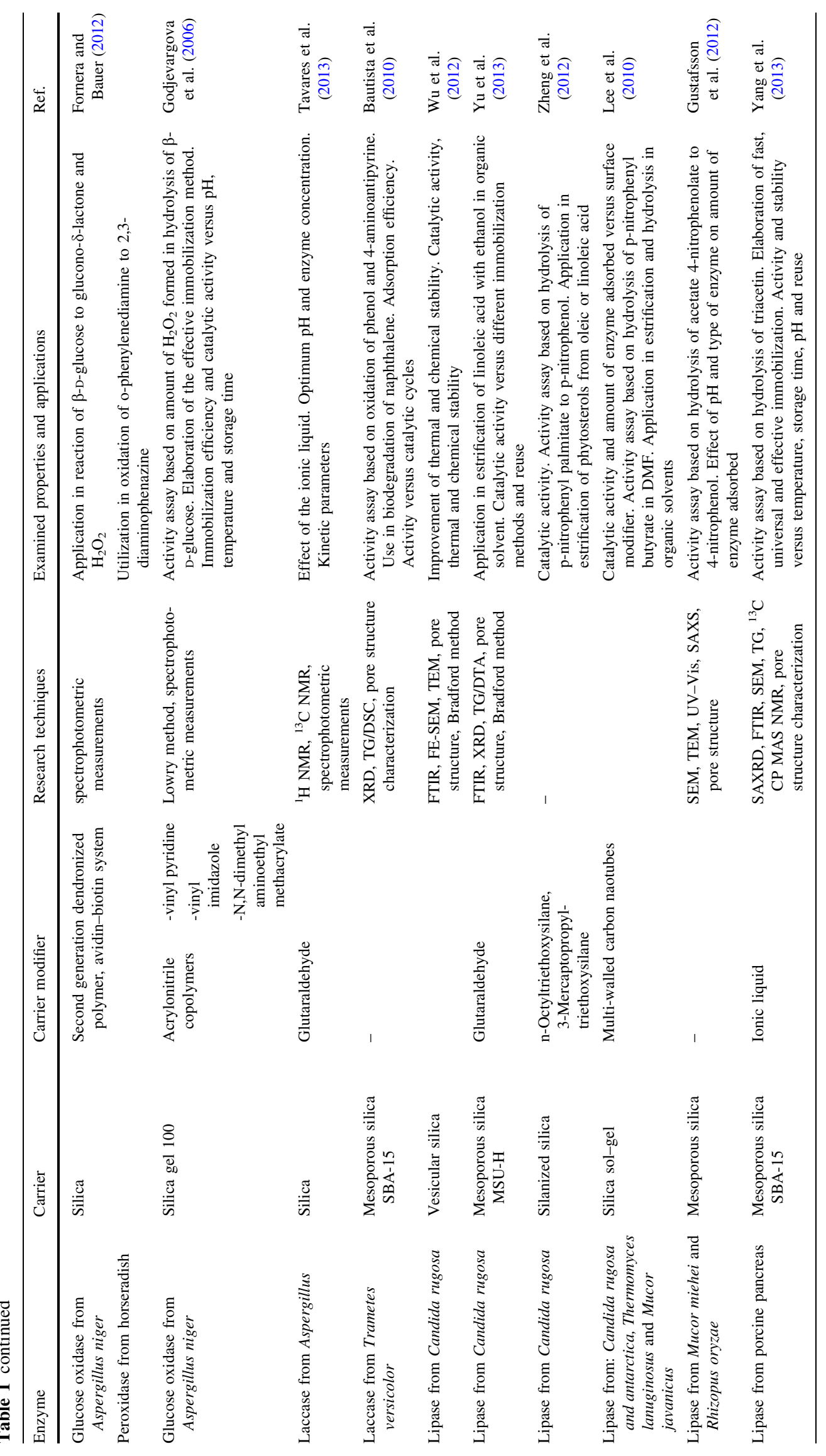




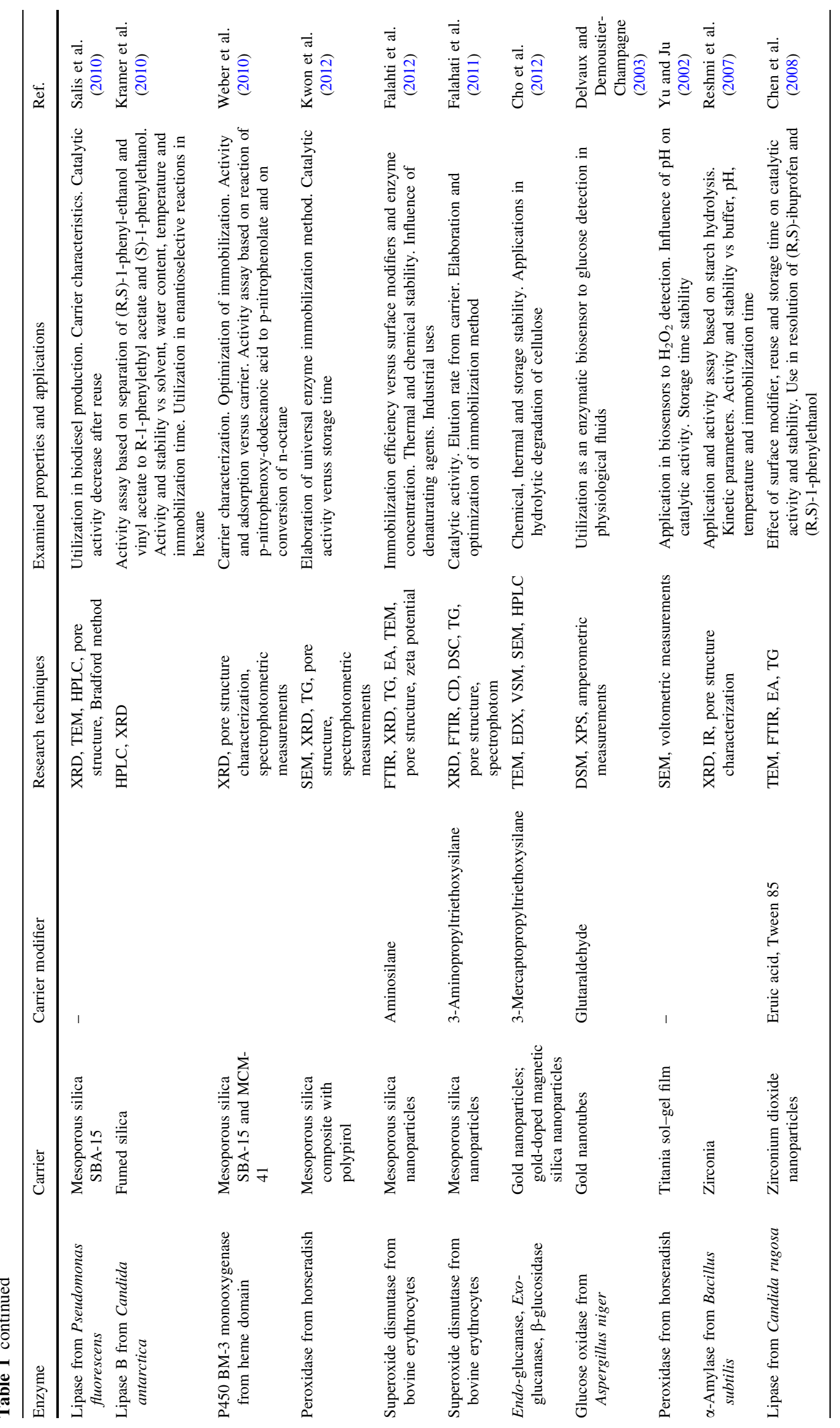




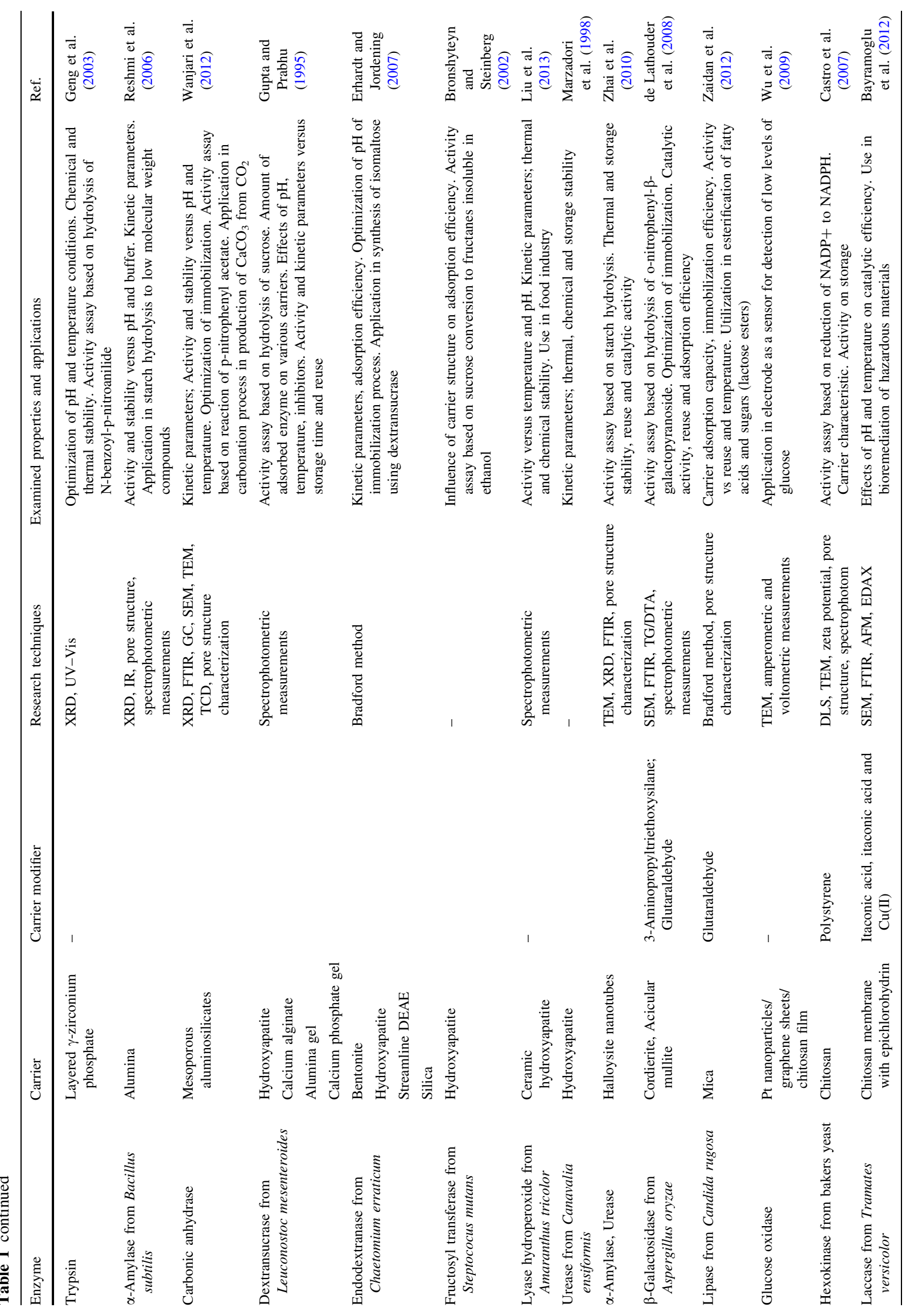




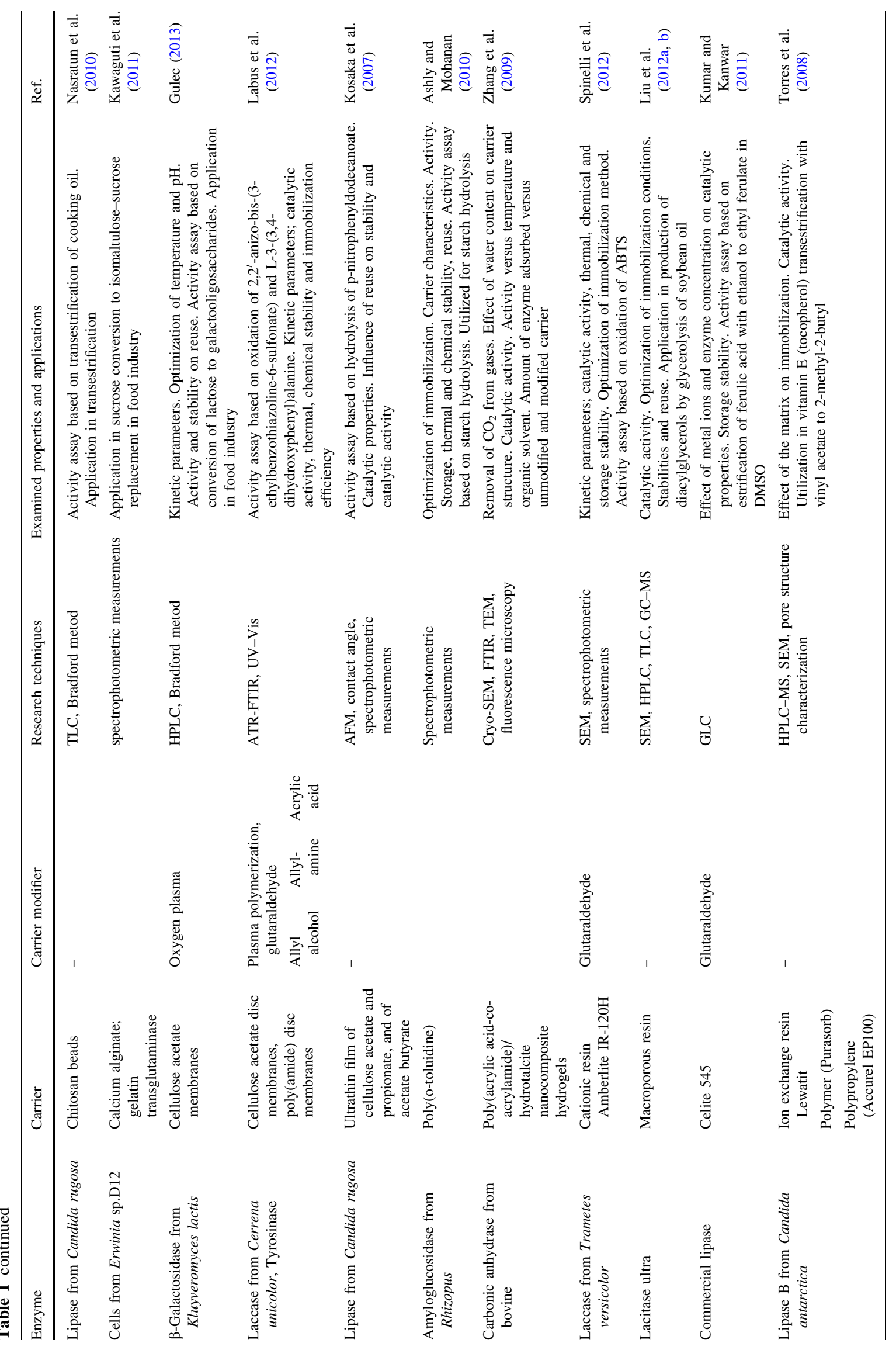




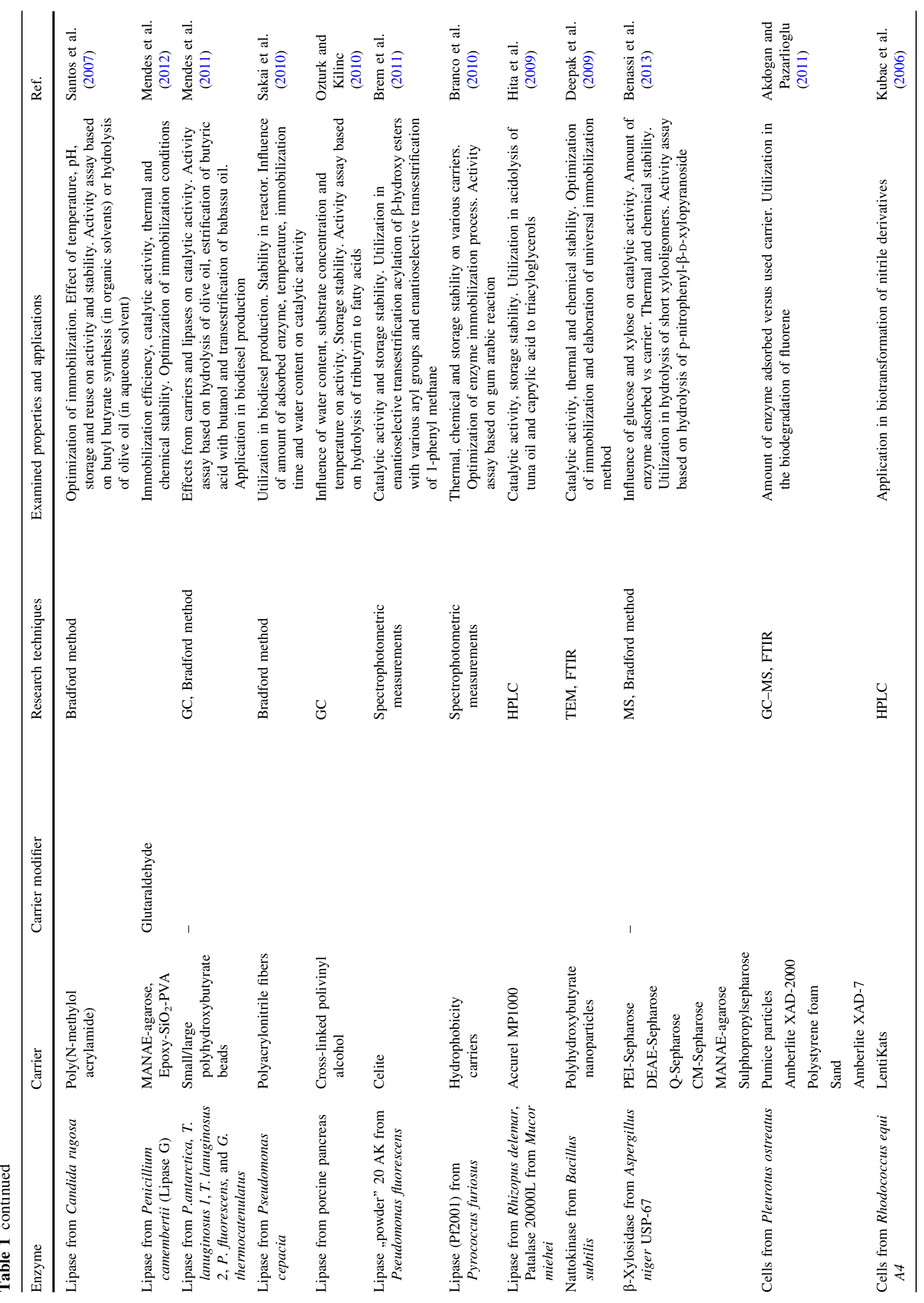




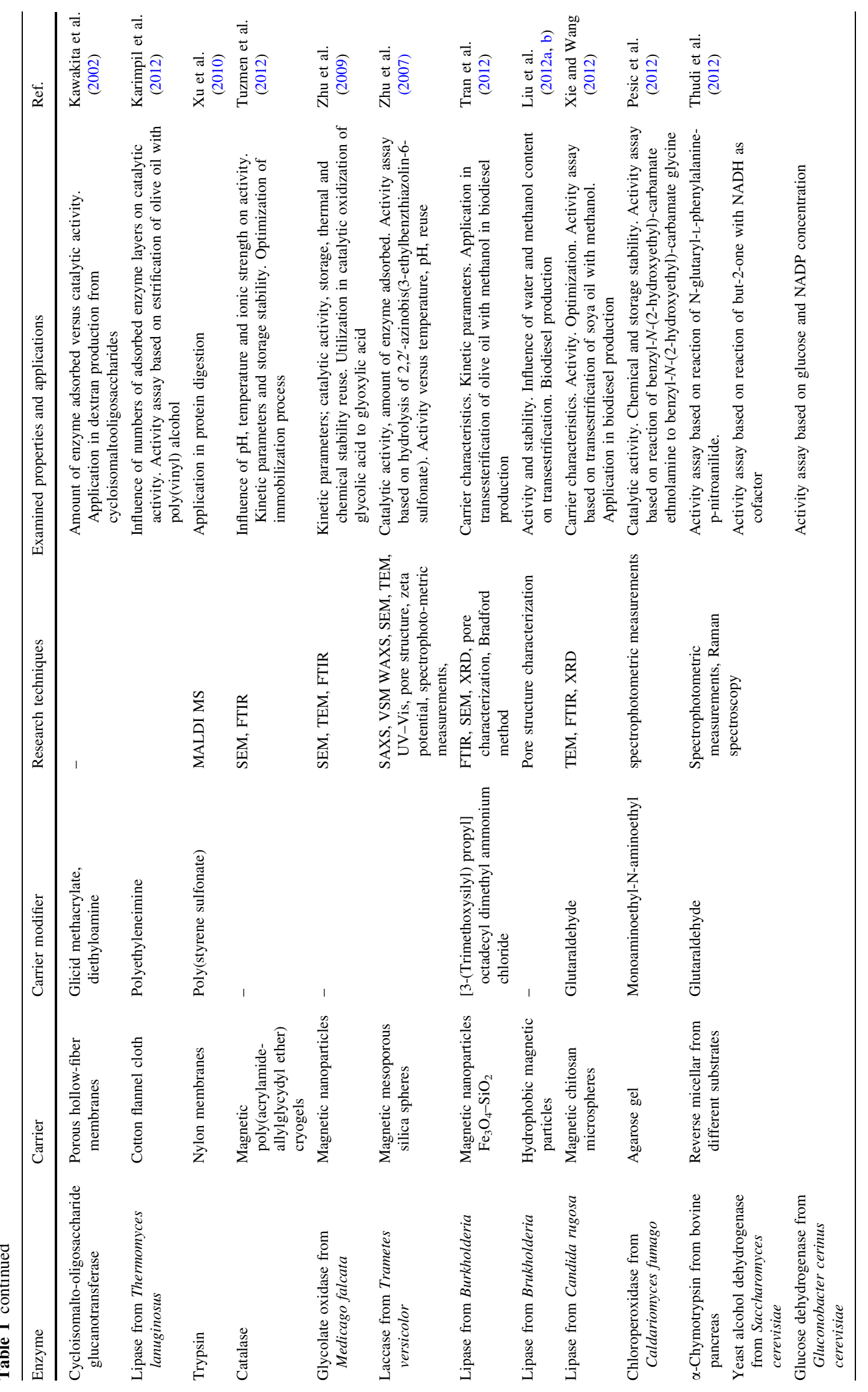




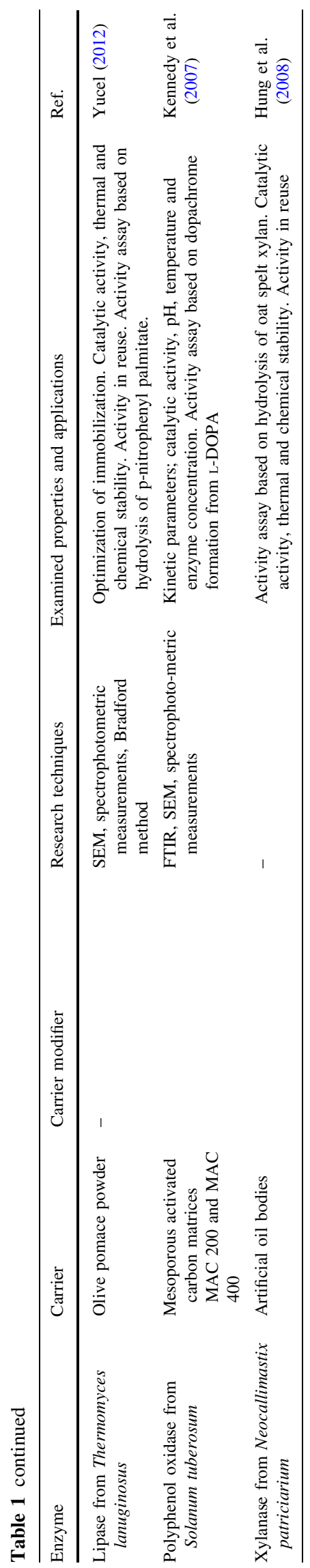

Other types of silicas used for the enzyme immobilization are vesicular silica and fumed silica. Vesicular silica (Zhou et al. 2011; Wu et al. 2012) has pores of a diameter ranging from 15 to $20 \mathrm{~nm}$, a pore volume from 0.6 to $1.4 \mathrm{~cm}^{3} / \mathrm{g}$ and surface area reaching $360 \mathrm{~m}^{2} / \mathrm{g}$, while fumed silica (Kramer et al. 2010) has particles of a diameter from 7 to $50 \mathrm{~nm}$ and a surface area of $255 \mathrm{~m}^{2} / \mathrm{g}$. These silicas have well-developed surface areas, small particles and high mechanical strength, which make them attractive alternatives to the other silicas described.

In order to enhance the affinity of the enzymes to silicas, the modifications of the matrices with polymers were proposed. The modifications consist in mixing silicas with polymers or coating them with polymers (Kwon et al. 2012). One group of polymers are polyamidoamine dendrimers (Wang et al. 2013). These are highly branched complex compounds, which due to the presence of amino groups in their structure, facilitate the development of the enzyme-carrier bonds, thereby giving rise to a more effective immobilization. For instance, it was observed that with an increasing content of the dendrimer on the silica surface, the amount of immobilized enzyme increased from $32 \mathrm{mg} / \mathrm{g}$ to almost $87 \mathrm{mg} / \mathrm{g}$ after a full modification of the silica. Polyamidoamine dendrimers were reported to enhance the affinity to cellulases, a group of enzymes catalysing the decomposition of cellulose by cleaving $\beta$-1,4-glycoside bonds. Importantly, the enzymes immobilized on polyamidoamine dendrimers modifiedsilicas retained over $80 \%$ of their activity after three full catalytic cycles. A similar effect was reported for a mesoporous silica-polypyrrole composite. The effect was ascribed to the presence of hydroxyl groups in polypyrrole. Another group of polymers applied for silica modifications are aptamers (Xiao et al. 2012). These are short oligonucleotide chains (DNA or RNA fragments) able to form specific bonds with the carrier and the biocatalyst.

The noble metal applied as a carrier for the enzyme immobilization is gold. The preparations made on the basis of gold are used mainly in the electrodes mounted in biosensors (Delvaux and Demoustier-Champagne 2003), but they can also be employed in biodegradation of cellulose (Cho et al. 2012). Gold is hardly soluble but easily malleable so its form can be well managed. For the enzyme adsorption, it is used in the form of nanoparticles, golddoped magnetic silica nanoparticles (Cho et al. 2012), and nanotubes (Delvaux and Demoustier-Champagne 2003).

Another inorganic carrier employed for the enzyme immobilization is a titania sol-gel film ( $\mathrm{Yu}$ and $\mathrm{Ju}$ 2002). Titanium dioxide is a white solid of high melting point and good adsorption parameters.

Zirconia, a white crystalline solid with a high melting point and high chemical resistance, is also an attractive for the enzyme immobilization, where it is used in the form of 
nanoparticles (Chen et al. 2008), layered $\gamma$-zirconium phosphate (Geng et al. 2003) and as pure zirconium (Reshmi et al. 2007).

In addition to the above-mentioned materials, also alumina gel (Gupta and Prabhu 1995) and aluminium (Reshmi et al. 2006) were tested as the enzyme carriers. Aluminium is a common, malleable and plastic metal. Its derivatives are mesoporous aluminosilicates (Wanjari et al. 2012), well characterized (Jaroniec and Fulvio 2013), which are a class of compounds made of aluminium, silicon and oxygen. They can be of either natural (zeolites) or synthetic origin.

Some enzymes were also reported to be immobilized on cordierite and mullite (de Lathouder et al. 2008). The former is a rare mineral belonging to the group of silicates, whereas the latter, a mineral related to aluminosilicates in structure and composition and it was used in the immobilization in the form of acicular mullite.

Other minerals reported as the enzyme carriers are halloysite (Zhai et al. 2010) and mica (Zaidan et al. 2012). Mica is a multi-element mineral of a complex chemical composition that includes mainly aluminium, silicon, calcium, sodium and potassium, and in smaller amounts, lithium, magnesium, iron and manganese. The benefits offered by mica are its high thermal and chemical resistance.

Hydroxyapatite is another mineral used as a carrier for the immobilization of enzymes by adsorption (Fargues et al. 1998; Marzadori et al. 1998; Bronshyteyn and Steinberg 2002). Built of calcium, phosphorus, oxygen and hydrogen, hydroxyapatite is easily available; it occurs in nature and can also be chemically synthesized. Being a component of bones, hydroxyapatite shows high biocompatibility. It also displays high resistance to a wide range of reaction conditions. Its important advantage is the ability to bind practically all enzymes, where it is typically used as a powdered solid or as ceramic hydroxyapatite (Liu et al. 2013).

Also bentonite was reported to be an enzyme carrier with high protein adsorption capacity (Erhardt and Jordening 2007). Bentonite does not dissolve in water but readily swells, which is why bentonite-supported enzymes can be used in water environments.

Useful as a carrier in the enzyme immobilization also appeared to be a mesoporous activated carbon (Kennedy et al. 2007) of different pore sizes, such as MAC 200 and MAC 4000.

\subsection{Organic carriers}

Of particular interest among organic carriers for the enzyme adsorption is chitosan (Krajewska 2004; Nasratun et al. 2010; Bayramoglu et al. 2012). Chitosan is a polyaminosaccharide obtained from chitin by deacetylation.
Chitosan is a nontoxic, biocompatible and gel-forming cationic compound that can readily be prepared in different geometrical configurations, such as membranes, beads, nanoparticles, fibers, hollow fibers or sponges (Krajewska 2005). It can also be applied in the microcrystalline form (Castro et al. 2007). The special advantage of chitosan is that when dissolved in acidic solutions, it bears multiple positive charges on $-\mathrm{NH}_{3}{ }^{+}$groups along its linear chains. This feature allows it to readily develop electrostatic interactions with molecules containing negatively charged groups (Alatorre-Meda et al. 2009; Krajewska et al. 2011, 2013a, b). Another adavantage of chitosan is that it can easily be chemically modified, which is possible due to the presence of modifiable functional groups $\left(-\mathrm{NH}_{2}\right.$ and $\left.-\mathrm{OH}\right)$ on chitosan chains (Honarkar and Barikani 2009).

A common organic compound used as an enzyme carrier is calcium alginate [Gupta and Prabhu 1995]. Alginate is an anionic polysaccharide that offers attractive gel-forming, concentrating and stabilizing properties. Commercial varieties of alginate are extracted from seaweeds, including the kelp Macrocystis pyrifera, Ascophyllum nodosum, and various types of algae from Phaeophyceae family. In addition to its pure form, it can also be used admixtured, e.g. with gelatin and transglutaminase (Kawaguti et al. 2011). It easily forms spherical particles with a welldeveloped surface area that endow it with good adsorption properties.

Alternatively used, organic carrier is cellulose. This is a polysaccharide of natural origin, made of glucose molecules. On the industrial scale, cellulose is obtained from wood. It is frequently used in the form of colourless cellulose acetate. It is a thermoplastic but hardly combustible polymer, insoluble in water. Different structures made of cellulose acetate are utilized, e.g. cellulose acetate membranes (Gulec 2013), cellulose acetate disc membranes (Labus et al. 2012) or ultrathin film of cellulose admixtured with acetate propionate and acetate butyrate (Kosaka et al. 2007).

Agarose gel (Pesic et al. 2012), a polysaccharide polymer, typically applied for separation of nucleic acids, is also used for enzyme immobilization, which is due to its morphological structure and beneficial adsorption properties.

In addition to natural polymers, synthetic polymers form a large and varied group of the enzyme carriers (Kumar and Kanwar 2011; Brem et al. 2011). Effectively, any polymerization can be designed to prepare a polymer with the customized properties. These properties can also be adapted by preparing the polymer composites. The synthetic polymers most commonly used as enzyme carriers include: poly(vinyl alcohol) (PVA) (Mendes et al. 2012) (commercial product LentiKats) (Kubac et al. 2006); crosslinked poly(vinyl alcohol) (Ozturk and Kilinc 2010); poly(N-methylolacrylamide) (Santos et al. 2007); 
polypropylene (commercial products Accurel EP100 (Torres et al. 2008) and Accurel MP1000 (Hita et al. 2009); polystyrene in the form of foam (Akdogan and Pazarlioglu 2011), in which immobilization is facilitated by a large number of pores; and poly(acrylic acid-co-acrylamide)/ hydrotalcite nanocomposite hydrogels (Zhang et al. 2009). An interesting enzyme carrier is the biodegradable and thermo-shrinkable hydroxybutyrate. It is used in the form of poly(hydroxybutyrate) nanoparticles (Deepak et al. 2009) and small or large poly(hydroxybutyrate) beads (Mendes et al. 2011). Another carrier, poly(o-toluidine) built of particles of o-toluidine isomer has active $-\mathrm{NH}_{2}$ groups (Ashly and Mohanan 2010). Furthermore, poly(acrylonitrile) (PAN), a polymer widely used in the production of synthetic fibres, as an enzyme carrier is used in the form of electrospun fibres (Sakai et al. 2010). PAN mats are about $25 \mu \mathrm{m}$ thick and they are made to have a radius of about $400 \mathrm{~nm}$. The material is very simple and its production is inexpensive. The stiff and elastic PAN carriers show high porosity and ability to interact with other materials, including enzymes and can be used in the various types of the reactors.

The carriers for the enzyme adsorption, if prepared in the form of membranes, e.g. as porous hollow fibre membranes (Kawakita et al. 2002), cotton flannel cloth (Karimpil et al. 2012) and nylon membranes (Xu et al. 2010), are special as they serve both as an enzyme support and at the same time as a separation phase, which, for instance, can separate the reagents of different molar masses.

An interesting option seems to be the carriers containing magnetic particles in their structure (Zhang et al. 2008; Zhu et al. 2009; Tran et al. 2012). Such magnetic matrices provide a good control of the process, as upon application of the magnetic field, the immobilized enzyme can be isolated and the catalyzed reaction terminated. Examples of such magnetic carriers include: a mixture of silicas with iron(II) and iron(III) oxides (Zhu et al. 2007); chitosan microspheres (Xie and Wang 2012); magnetic poly(acrylamide-allylglycydyl ether) cryogels (Tuzmen et al. 2012); and hydrophobic magnetic particles (Liu et al. 2012a, b).

Commercially available, ion-exchange resins, such as Lewatit (Wu et al. 2009), Amberlite IR-120H (Spinelli et al. 2012) or Amberlite XAD-2000 and Amberlite XAD-7 (Akdogan and Pazarlioglu 2011), typically used in the form of gels, are characterized with a highly developed porous structures and the presence of multiple active groups. These characteristics allow them to act as good enzyme supports.

Beside the materials described above, there are also substances, which although less frequently utilized in enzyme immobilizations, feature good adsorption properties, examples being artificial oil bodies (Hung et al. 2008) and olive pomace powder (Yucel 2012). An interesting approach to the immobilization of enzymes is also the use of reverse micelles (Thudi et al. 2012), in which the hydrophobic part is directed outside the micelle to allow an enzyme attachment.

\subsection{Commercial products}

An example of commercially available enzyme carriers is Stremaline DEAE (Erhardt and Jordening 2007), which is a composite made of agarose with a quartz core and diethylaminoethyl ligands on the surface. Another example are the epoxy-activated polymer supports, such as Eupergit (Katchalski-Katzir and Kraemer 2000; Erhardt and Jordening 2007) commercialized by Rhon Haas and Sepabeads commercialized by Resindion (Barbosa et al. 2013). Both are available in the form of macroporous beads. Eupergit supports are copolymers, of which a main component is poly(methacryl amide), while Sepabeads are polystyrenic adsorbents. Commercially available are also Celite (Kumar and Kanwar 2011) and Celite 545 silica carriers (Brem et al. 2011). Their main component is diatomaceous earth, which is the sedimentary rock formed as a result of diatoms exoskeletons deterioration. In the naturally occurring form it is admixtured with crystobalite, quartz and alumina. Its particle size varies from a few micrometers to a millimetre, but in the commercial product it has particles of diameters from 10 to $200 \mu \mathrm{m}$. Also worthy of note is Sepharose, a crosslinked, beaded-form of agarose, a polysaccharide polymer material extracted from seaweed. The great advantage of Sepharose is that its surface can be chemically modified in order to better adapt it to the functional groups of the protein (Benassi et al. 2013). Chitosan is another biopolymer manufactured for the enzyme immobilization and marketed under the brand name Chitopearl (Fuji Spinning, Tokyo, Japan) (Krajewska 2004). Different Chitopearl beads are produced and they can differ in the type and length of side ligands to be rightly chosen for a particular immobilization. The commercial products utilized in enzyme adsorption also include a group of polyvinyl supports available under the name Lentikats (Kubac et al. 2006), as well as the polymer matrices Accurel EP100 (Torres et al. 2008) and Accurel MP1000 (Hita et al. 2009).

\subsection{Summary of data on enzyme carriers}

The foregoing presentation of materials considered and studied for immobilizing enzymes by adsorption, shows that their variety is very rich. It includes organic and inorganic, natural and synthetic materials, that may be configured as beads of different sizes, membranes, fibers, hollow fibers, capsules, sponges in order to best match the conditions of a specific biotransformation in a given 
bioreactor. Importantly, it also shows that there are no universal carriers for all enzymes and their applications. Effectively, the choice of a specific material is determined by many factors and for each enzyme and each process this should be made individually, as it may happen that a drawback of one material in one process can be its advantageous feature in another one. The following general comment on the enzyme carrier materials can, however, be proposed. Silicas are perhaps the most common enzyme carriers. Their features, advantageous for this application result chiefly from the well-developed surface area, high availability and low cost. High thermal stability and chemical resistance shown by silica materials are also characteristic for minerals, such as mica or hydroxyapatite. The carriers based on metals, such as titanium, aluminium or zirconium, also show high mechanical strength; however, they show higher affinity to some groups of enzymes, which restricts their application. The magnetic organic and inorganic carriers, which use permits a good control of the enzymatic process, have become very popular but their widespread use is limited by their high cost. For the same reason, the use of carriers based on gold is limited. The interest in materials of natural origin, such as chitin, chitosan or cellulose, stems from their high biocompatibility and availability, but their application is limited by their selective affinity to certain enzymes, but foremost by their lower durability in the process conditions as compared to inorganic materials. By contrast, synthetic polymer matrices are widely used for enzyme adsorption, as they can be tailored to suite the specific enzyme and the conditions of a specific process. Moreover, their production is relatively facile and rapid, and what is more, they show high thermal and chemical resistance.

\section{Surface modifying agents}

The prerequisite for the successful immobilization of an enzyme by adsorption on a solid carrier is the existence of specific functional groups on the surface of both the enzyme and the carrier. These give rise to the interactions sufficiently strong for the enzyme-carrier binding (adsorption) to occur (Kosaka et al. 2007; Gustafsson et al. 2012; Wu et al. 2012). When such groups are absent, the carrier is subjected to a chemical modification (Cho et al. 2012; Mendes et al. 2012; Zaidan et al. 2012).

The modifying agent should have at least two reactive groups in its molecule; one should enable it to chemically anchor on the carrier and the other one, to physically interact with the enzyme. Typical compounds meeting this condition are bifunctional carbonyl compounds, among them glutaraldehyde being apparently most common (see Fig. 4) (Delvaux and Demoustier-Champagne 2003; de
Lathouder et al. 2008; Thudi et al. 2012). Glutaraldehyde with the formula $\mathrm{CH}_{2}\left(\mathrm{CH}_{2} \mathrm{CHO}\right)_{2}$ contains two reactive aldehyde groups. It is used as a disinfectant and preservative. Having high affinity to bacteria, fungi and proteins, it is a good enzyme immobilizer. Also, beneficially for the immobilization, its five-atom carbon chain serves as a spacer for enzymes, making their active sites easier accessible for the substrates.

Compounds frequently used as the carrier modifiers for adsorption of enzymes are also silanes, such as 3-aminopropyltrimethoxysilane (Mansur et al. 2001; Zhou et al. 2011) and 3-aminopropyltriethoxysilane (Falahati et al. 2011, 2012; Vinoba et al. 2012), mercaptopropyltrimethoxysilane and mercaptopropyltriethoxysilane (Cho et al. 2012). The latter two compounds interact stronger with the carrier surface, which is due to the presence of three methoxy or ethoxy groups in their molecules. In the process of surface functionalization, the groups undergo hydrolysis to hydroxyl groups allowing the formation of hydrogen and covalent bonds with the carrier. On the contrary, the presence of $-\mathrm{SH}$ or $-\mathrm{NH}_{2}$ groups compatible with the enzyme functional groups, facilitates generation of carrier-modifier-enzyme interactions. Other trialkylsilanes used as carrier modifiers include n-octyltriethoxysilane (Zheng et al. 2012), phenyltrimethoxysilane, vinyltrimethoxysilane (Hartono et al. 2010) and [3-(trimethoxysilyl)propyl] octadecyl dimethyl ammonium chloride (Tran et al. 2012). The attachment of the most common surface modifying agents to silica particles is shown in Fig. 3.

Polymers constitute another group of useful compounds for a carrier modification. Their usefulness originates from the fact that they can be chemically prepared of monomers desired for a given process and their chain lengths can be controlled. Polyethyleneimine (Karimpil et al. 2012), polystyrene (Castro et al. 2007) and poly(styrene sulfonate) (Xu et al. 2010) are widely applied. In addition to the branched second generation dendronized polymers (Fornera and Bauer 2012), the use of acrylonitrile copolymers was also reported (Godjevargova et al. 2006). This compound generates interactions with vinyl pyridine, vinyl imidazole and N,N-dimethyl-aminoethyl-methacrylate.

Owing to both acid-base properties and the ability to form hydrogen bonds, amines are also considered as carrier modifiers, the most common among them being diethylamine (Kawakita et al. 2002), diethylaminoethyl (DEAE) (Karboune et al. 2005) and monoaminomethyl- $N$-aminoethyl as an agarose gel modifier (Pesic et al. 2012)

Also, carboxylic acids have properties classifying them for the use as modifiers. An example of a long-chain carboxylic acid is erucic acid (Chen et al. 2008), while a shortchain carboxylic acid containing two carboxyl groups and an additional reactive carbonyl group is itaconic acid (Bayramoglu et al. 2012), both shown in Fig. 4. 
(a)
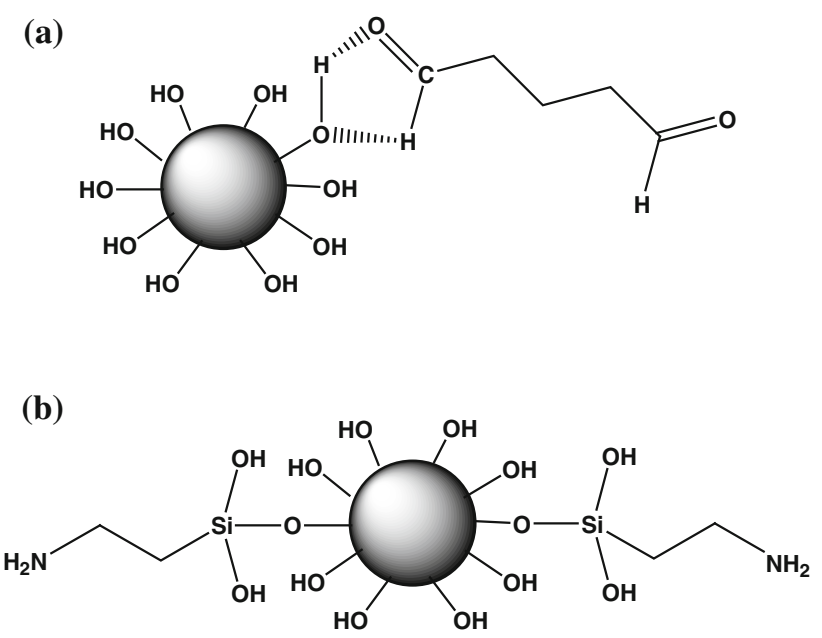

(c)<smiles>OC1C(O)C(O[Si](O)(O)CCS)C(O)C(O)C(O)C(O[Si](O)(O)CCS)C1O</smiles>

(d)

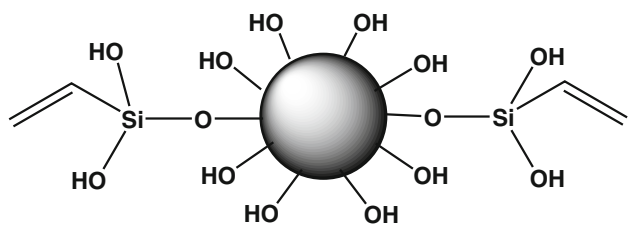

Fig. 3 Representative silica surface modifying agents used in enzyme immobilization, a silica particle grafted with glutaraldehyde, b silica particle modified with 3-aminopropyltriethoxysilane, $\mathbf{c}$ silica particle functionalized with mercaptopropyltriethoxysilane, $\mathbf{d}$ silica particle grafted with vinyltrimethoxysilane

A new approach to a carrier functionalization is the use of plasma. Oxygen plasma (Gulec 2013) and plasma polymerization: allyl alcohol, allyl amine and acrylic acid were proposed (Labus et al. 2012). The high cost is, however, a serious disadvantage of the method.

\section{Immobilized enzymes}

The unquestionable advantage of the enzyme immobilization by adsorption process is the versatility. The method can be applied for the enzymes of different types, which catalyse diverse sorts of reactions. Clearly, it is not possible to immobilize any enzyme on any carrier. The range of carriers for a given enzyme is limited by the enzyme-

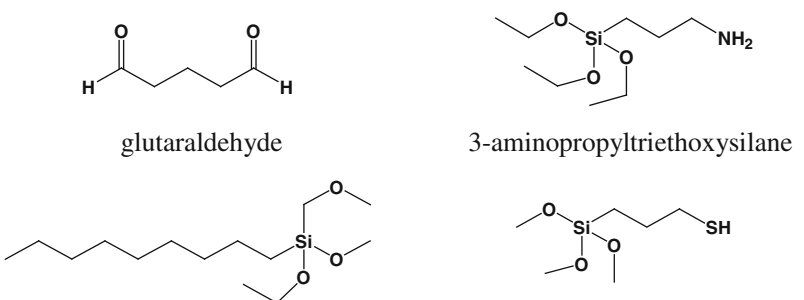

n-octyltriethoxysilane

mercaptopropyltrimethoxysilane

$$
\text { vinyltrimethoxysilane }
$$

polyethyleneimine<smiles>CC[N+](C)(CC)CCOC</smiles>

diethylaminoethyl (DEAE)<smiles>C=C(CC(=O)O)C(=O)O</smiles>

itaconic acid<smiles>CCCCCCCCCCCCCCCC(=O)O</smiles>

Fig. 4 Representative surface modifying agents used in enzyme immobilization

carrier affinity. However, it is possible to propose a carrier that will be optimal for assuring both the desired parameters of the process and the target properties of the immobilized enzyme.

Enzymes most commonly studied in the immobilized form are lipases (Sakai et al. 2010; Adlercreutz 2013; Ansorge-Schumacher and Thum 2013). Lipases catalyse the hydrolysis of esters formed by short- and long-chain alcohols, mono- and multi-hydroxides, and saturated and unsaturated carboxylic acids of short and long chains. The catalysts based on lipases are used in the reactions of esterification or transesterification of different substrates (Brem et al. 2011; Liu et al. 2013; Yu and Fang 2013), and in the process of biodiesel production (Salis et al. 2010; Mendes et al. 2011; Tran et al. 2012). A wide use of this group of proteins and their affinity to many carriers permit their immobilization on many organic and inorganic carriers. Organic carriers seem to be preferred for the immobilization of lipases. They include a wide and highly diverse gamut of polymers, such as cross-linked PVA (Ozturk and Kilinc 2010) and epoxy activated PVA (Mendes et al., 2012), poly( $N$-methylol acrylamide) (Santos et al. 2007), small and large poly(hydroxybutyrate) beads (Mendes et al. 2011) and polyacrylonitryle electrospun fibres (Sakai et al. 2010), organic matrices of natural origin, including chitosan beads (Nasratun et al. 2010), MANAE-agarose and cellulose ultrathin film (Kosaka et al. 2007), commercial polymer products, e.g. polypropylene 
Fig. 5 Lipase immobilization onto glutaraldehyde-modified silica surface
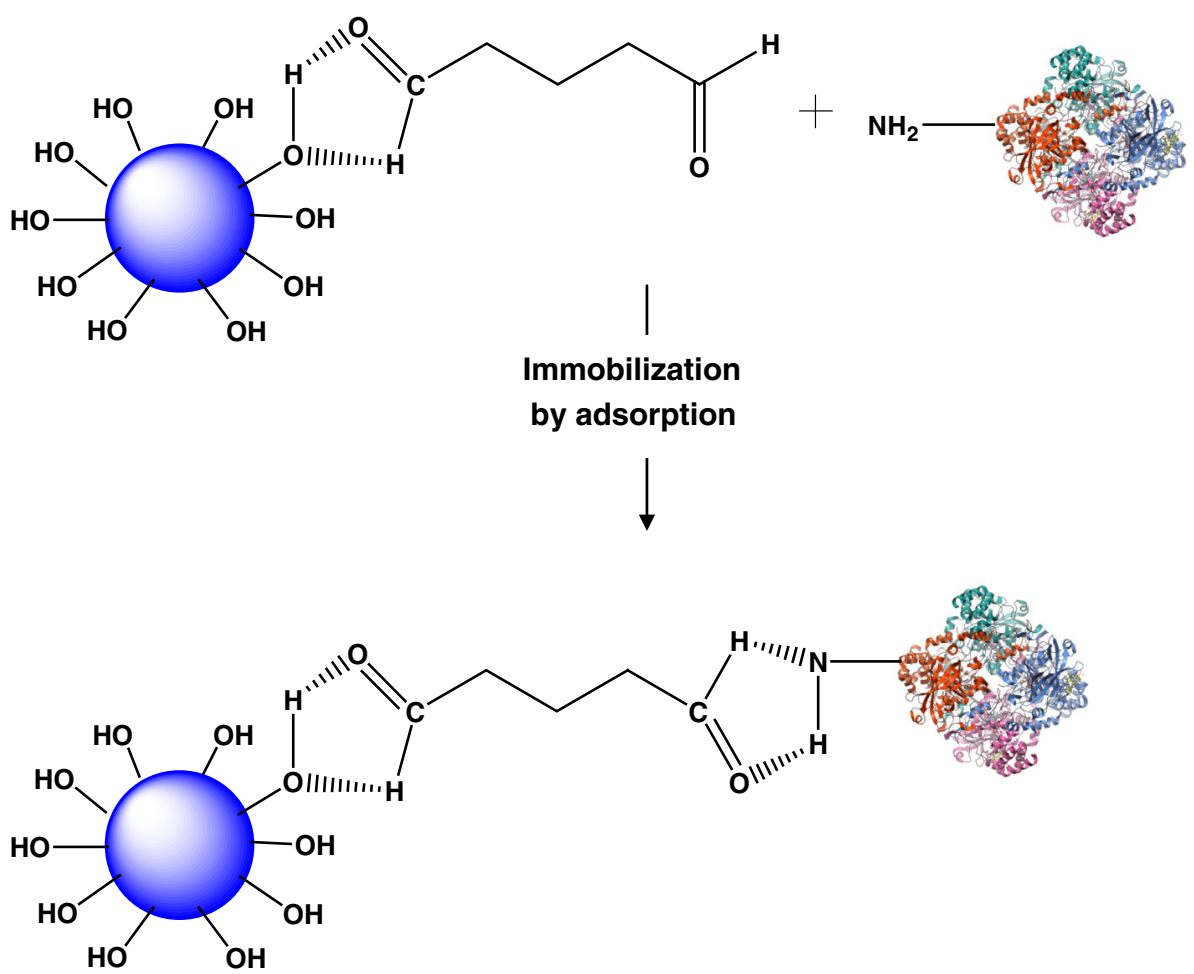

membranes Accurel EP100 and Accurel MP1000 (Hita et al. 2009), adsorbent Purasorb (Torres et al. 2008). Lipases were also immobilized on other materials such as buthyl and octadecyl sepabeads (Branco et al. 2010), cotton flannel cloth (Karimpil et al. 2012), olive pomace powder (Yucel 2012) and commercial ion exchange resin Lewatit. By contrast, among inorganic carriers widely used there are different silicas, such as mesoporous silicas (Gustafsson et al. 2012), e.g. SBA-15 (Yang et al. 2013) or MSU-H (Yu and Fang 2013), vesicular silica (Wu et al. 2012), fumed silica (Kramer et al. 2010), silanized silica (Zheng et al. 2012), silica sol-gel film (Lee et al. 2010) and commercial silica-based products Celite (Brem et al. 2011) and Celite 545 (Kumar and Kanwar 2011; see Fig. 5). Other inorganic carriers used for the adsorption of lipases are zirconia nanoparticles (Chen et al. 2008), mica (Zaidan et al. 2012), and magnetic carriers (Liu et al. 2012a, b; Xie and Wang 2012).

An interesting immobilization of lipases was performed in sol-gel derived silica using the multi-walled carbon nanotubes as additives to protect the inactivation of the enzymes during the sol-gel process and to enhance their stability. The immobilized lipases displayed not only higher activities, but also active lifetime as much as five times longer than that of the free enzymes. Similar effects were also observed when a mesoporous silica carrier was modified by carboxyl-functionalized ionic liquid (Yang et al. 2013).

In contrast, in the process of the lipase adsorption on zirconia nanoparticles, it was demonstrated that the nanoparticles modified with a carboxylic surfactant of a long alkyl chain significantly enhanced the activity and enantioselectivity of the immobilized lipases in the organic media (Chen et al. 2008). The use of the surfactant in the preparation changed the surface of the nanoparticles from hydrophilic to hydrophobic. It was interpreted that the interaction between the hydrophobic surface of zirconia and lipases induced the conformational rearrangement of lipases into an active, stable form.

Another group of the enzymes of extensive industrial significance, preferably used in the immobilized form, are amylases (Reshmi et al. 2006; Bellino et al. 2010). The catalysts based on amylases are used on the industrial scale for the hydrolysis of starch. In contrast to lipases, amylases are more specific and their immobilization is possible mostly on inorganic matrices, including mesoporous silicas, such as SBA-15 (Ajitha and Suguman 2010) or silica thin film (Wang et al. 2013), and also silica gel (Nwagu et al. 2011), halloysite nanotubes (Zhai et al. 2010) and metals, such as zirconium and aluminium.

Laccase is another enzyme used in the industry in the immobilized form (Bayramoglu et al. 2012; Xie and Wang 2012). Its major task is to oxidize simple phenolic derivatives, as well as other compounds containing aromatic moieties. The enzyme can thus be used in bioremediation (Bautista et al. 2010). Interestingly, laccase shows an affinity to organic carriers, which is considerably higher comparing to the inorganic carriers. In this context it was immobilized on chitosan membrane (Reshmi et al. 2007), 
cellulose acetate disc membranes (Labus et al. 2012) and commercial cationic resin Amberlite IR-120H (Spinelli et al. 2012). Among inorganic carriers, the enzyme was immobilized on different silicas (Tavares et al. 2013), e.g. on the commercial mesoporous SBA-15 (Bautista et al. 2010), on magnetic mesoporous silica spheres (Zhu et al. 2007) and on silica gels functionalized with different organosilanes (Rekuc et al. 2010).

Another group of the immobilized enzymes utilized on the industrial scale are oxidases (Kennedy et al. 2007; Zhu et al. 2009; Fornera and Bauer 2012). They are widely applied for catalyzing redox reactions that involve molecular oxygen as an electron acceptor. In these reactions oxygen is reduced to water or hydrogen peroxide. Of special significance in this enzyme family is the glucose oxidase. The reason is that this enzyme is applied in glucose biosensors, which are exploited as measuring devices in real time, in situ measurements, for instance in food industry, but foremost in medicine. Notably, the immobilization of the glucose oxidase was shown to enable constructing glucose biosensors with improved durabilities, sensitivities, linear ranges and detection limits (Delvaux and Demoustier-Champagne 2003; Wu et al. 2009; Zhou et al. 2011).

Another enzymes from the oxidases family are peroxidases, which catalyze the reactions of oxidation, commonly with hydrogen peroxide as a substrate, and are also used in the immobilized form, mainly for the treatment of industrial wastewaters (Montiel et al. 2007; Pesic et al. 2012). The immobilized peroxidases are also used in biosensors for detection of $\mathrm{H}_{2} \mathrm{O}_{2}$ ( $\mathrm{Yu}$ and $\mathrm{Ju}$ 2002). According to the literature, these enzymes are immobilized mainly on inorganic silica-based carriers, such as mesoporous silica (Fornera and Bauer 2012), commercial SBA-15 (Zhou et al. 2011), rod-like and vesicle-like mesoporous silica (Zhou et al. 2011), silica gel SG/67 and silica gel 100 (Godjevargova et al. 2006), and also on magnetic nanoparticles based on $\mathrm{Fe}_{3} \mathrm{O}_{4}$ (Zhu et al. 2009), gold nanotubes (Delvaux and Demoustier-Champagne 2003) and mesoporous activated carbon matrices MAC 200 and MAC 400 (Kennedy et al. 2007). Peroxidases were also immobilized on an inorganic-organic carrier that was made of platinum nanoparticles/graphene sheets/chitosan film (Wu et al. 2009), where the enzyme-carrier interactions were mediated by the chitosan film.

Immobilization by adsorption has also been applied to other enzymes, such as carbonic anhydrases. This group of enzymes catalyzes the reversible interconversion of carbon dioxide and water to bicarbonate and protons. It has been proposed to exploit the reaction in $\mathrm{CO}_{2}$ capture and storage (Fransen et al. 2013). In the process, commonly known as mineral carbonation (Wanjari et al. 2012; Vinoba et al. 2012; Zhang et al. 2009), carbonic anhydrase serves to catalyze the $\mathrm{CO}_{2}$ hydration. If performed in the presence of $\mathrm{Ca}^{2+}$ ions, the reaction is followed by $\mathrm{CaCO}_{3}$ precipitation. This bio-based proposal constitutes a new, eco-friendly approach to capture, store or sequester $\mathrm{CO}_{2}$ done to avoid the growth of its concentration in the atmosphere. To prepare carbonic anhydrases for this process, the enzymes were adsorbed on inorganic carriers, such as mesoporous silica SBA-15 and mesoporous aluminosilicates, where their stabilities were greatly enhanced, as well as on the complex organic system poly(acrylic acid-co-acrylamide)/ hydrotalcite nanocomposite hydrogel. An interesting example of enzymes of practical applications are also cellulases (Hartono et al. 2010; Chang et al. 2011), responsible for the hydrolysis of cellulose, for which they were immobilized on mesoporous silicas materials.

Among the noteworthy immobilized enzymes there are also ureases (Krajewska 2009b; Marzadori et al. 1998; Zhai et al. 2010; Krajewska et al. 1990). The enzymes are responsible for the hydrolysis of urea to carbonic acid and ammonia (Krajewska 2009a, Krajewska et al. 2012). The reaction can be exploited in removal of urea from aqueous solutions that is a problem faced in numerous areas, examples being urea-producing industry, agriculture and natural environment, food production and medicine (Krajewska 2009b). In the latter area, an immobilized urease was considered as a part of the wearable/portable artificial kidney, alternative to the classical hemodialytic device. Important are also analytical applications of immobilized ureases in various biosensing systems, mainly biosensors both for the determinations of urea and of pollutants that are urease inhibitors (Krajewska et al. 1997; Krajewska and Zaborska 2007) (spectrometric, potentiometric, conductometric, amperometric, acoustic, thermal) (Krajewska 2009b). Practical, cost-effective and portable analytical devices, especially useful in the in situ and real-time measurements. The biosensors are predicted to become widely accepted for use, once their storage and operational stabilities are improved.

An overview of enzymes immobilized by adsorption is presented in Table 1 along with the carriers, on which they were immobilized, carrier-modifiers, with which carriers had their surfaces modified, techniques that the systems were studied with, and importantly, their properties and possible applications. The overview may thus serve as a guide for making the right choices while preparing enzymes immobilized by adsorption.

\section{Conclusions}

Enzymes as the effective catalysts have advantageous features, among which the high catalytic efficiency, specificity and mild conditions of operation made them 
attractive alternatives to the chemical catalysts for a great variety of applications. This has intensified the studies on the immobilization of the enzymes, in order to improve their catalytic properties. From many methods proposed for the enzyme immobilization, the most common is the adsorption on the solid carriers. The most important advantage of this immobilization is that a wide gamut of carriers can be used and that the enzymes of practically each class can be immobilized. Equally important is the fact, that this immobilization leaves the enzyme structure intact, which allows enzymes to retain their activity and also facilitates the transport of the substrates to the enzyme's active centre. Comparing with the chemical enzyme immobilizations, a disadvantage of enzyme adsorption is a low stability of the immobilized enzymes, which may lead to a fast washing out of the enzyme from the carrier. However, as follows from the presented survey of the literature overview, the adsorption remains the fastest and most universal method of the enzyme immobilization.

Acknowledgments This work was supported by research Grant no. 3/32/443-DS-PB/2014 from Poznan University of Technology, Poznań, Poland (TJ, JZ), and by DS WCh/43 from the Faculty of Chemistry of the Jagiellonian University, Kraków, Poland (BK).

Open Access This article is distributed under the terms of the Creative Commons Attribution License which permits any use, distribution, and reproduction in any medium, provided the original author(s) and the source are credited.

\section{References}

Adlercreutz, P.: Immobilisation and application of lipases in organic media. Chem. Soc. Rev. 42, 6406-6436 (2013)

Ajitha, S., Suguman, S.: Tuning mesoporous molecular sieve SBA-15 for the immobilization of $\alpha$-amylase. J. Porous Mater. 17, 341-349 (2010)

Akdogan, H.A., Pazarlioglu, N.K.: Fluorene biodegradation by $P$. osteratus-part II: biodegradation by immobilized cells in a recycled packed bed reactor. Proc. Biochem. 46, 840-846 (2011)

Alatorre-Meda, M., Taboada, P., Sabin, J., Krajewska, B., Varela, L.M., Rodriguez, J.R.: DNA-chitosan complexation: a dynamic light scattering study. Colloid Surf. A 339, 145-152 (2009)

Ansorge-Schumacher, M.B., Thum, O.: Immobilised lipases in the cosmetics industry. Chem. Soc. Rev. 42, 6475-6490 (2013)

Ashly, P.C., Mohanan, P.V.: Preparation and characterization of Rhizopus amyloglucosidase immobilized on poly(o-toluidine). Process Biochem. 45, 1422-1426 (2010)

Barbosa, O., Torres, R., Ortic, C., Berenguer-Murcia, A., Rodrigues, R.C., Fernandez-Lafuente, R.: Heterofunctional supports in enzyme immobilization: from traditional immobilization protocols to opportunities in tuning enzyme properties. Biomacromolecules 14, 2433-2462 (2013)

Bautista, L.F., Morales, G., Sanz, R.: Immobilization strategies for laccase Trametes versicolor on mesostructured silica materials and the application to the degradation of naphthalene. Bioresour. Technol. 101, 8541-8548 (2010)
Bayramoglu, G., Gursel, I., Yilmaz, M., Arica, M.Y.: Immobilization of laccase on itaconic acid grafted and $\mathrm{Cu}$ (II) ion chelated chitosan membrane for bioremediation of hazardous materials. J. Chem. Technol. Biotechnol. 87, 530-539 (2012)

Bellino, M.G., Regazzoni, A.E., Soler-Illia, G.J.A.A.: Amylasefunctionalized mesoporous silica thin films as robust biocatalyst platforms. Appl. Mat. Interfaces 2, 360-365 (2010)

Benassi, V.M., da Silva, T.M., Pesslea, B.C., Guisan, J.M., Mateo, C., Lima, M.S., Jorge, J.A., de Polizeli, M.L.T.M.: Immobilization and biochemical properties of $\beta$-xylosidase activated by glucose/ xylose from Aspergillus niger USP-67 with transxylosylation activity. J. Mol. Catal. B 89, 93-101 (2013)

Bhattacharyya, M.S., Singh, A., Banerjee, U.C.: Immobilization of intracellular carbonyl reductase from Geotrichym candidum for the stereoselective reduction of 1-naphthyl ketone. Bioresour. Technol. 101, 1581-1586 (2010)

Brady, D., Jordon, J.: Advances in enzyme immobilisation. Biotechnol. Lett. 31, 1639-1650 (2009)

Branco, R.V., Gutarra, M.L.E., Freire, D.M.G., Almeida, R.V.: Immobilization and characterization of a recombinant thermostable lipase (Pf2001) from Pyrococcus furiosus on suports with different degrees of hydrophobicity. Enzyme Res. 2010, 1-8 (2010)

Brem, J., Turcu, M.C., Paizs, C., Lundell, K., Tosa, M.I., Irimie, F.D., Kanerva, L.T.: Immobilization to improve the propeties of Pseudomonas flourescens lipase for the kinetic resolution of 3-aryl-3-hydroxy esters. Proc. Biochem. 47, 119-126 (2011)

Bronshyteyn, M., Steinberg, D.: Immobilization of fructosyltransferase from Streptococcus mutans on hydroxyapatite surfaces induces the formation of multimeric complexes. Lett. Appl. Microbiol. 34, 205-209 (2002)

Cao, L., van Langen, L., Sheldon, R.A.: Immobilised enzymes: carrier-bound or carrier-free? Curr. Opin. Biotechnol. 14, 387-394 (2003)

Cao, L.: Immobilised enzymes: science or art? Curr. Opin. Biotechnol. 9, 217-226 (2005)

Carrea, G., Riva, S.: Properties and synthetic applications of enzymes in organic solvents. Angew. Chem. Int. Ed. 39, 2226-2254 (2000)

Castro, L.B.R., Silva, F.F., Carmona-Ribeiro, A.M., Kappl, M., Petri, D.F.S.: Immobilization of hexokinase onto chitozan decorated particles. J. Phys. Chem. B 111, 8520-8526 (2007)

Chang, R.H.Y., Jang, J., Wu, K.C.W.: Cellulase immobilized mesoporous silica nanocatalysts for efficient cellulose-to-glucose conversion. Green Chem. 13, 2844-2850 (2011)

Chen, Y.Z., Yang, C.T., Ching, C.B., Xu, R.: Immobilization of lipases on hydrophobilized zirconia nanoparticles: highly enantioselective and reusable biocatalysts. Langmuir 24, 8877-8884 (2008)

Cho, E.J., Jung, S., Kim, H.J., Lee, Y.G., Nam, K.C., Lee, H.J., Bae, H.J.: Co-immobilization of three cellulases on Au-doped magnetic silica nanoparticles for the degradation of cellulose. Chem. Commun. 48, 886-888 (2012)

Choma, J., Kloske, M., Jaroniec, M., Klinik, J.: Benzene adsorption isotherms on MCM-41 and their use for pore size analysis. Adsorption 10, 195-203 (2004)

Cowan, D.A., Fernandez-Lafuente, R.: Enhancing the functional properties of thermophilic enzymes by chemical modification and immobilization. Enzyme Microb. Technol. 49, 326-346 (2011)

de Lathouder, K.M., van Benthem, D.T.J., Wallin, S.A., Mateo, C., Fernandez Lafuente, R., Guisan, J.M., Kapteijn, F., Moulijn, J.A.: Poliethyleneimine (PEI) functionalized ceramic monoliths as enzyme carriers: preparation and performance. J. Mol. Catal. B 50, 20-27 (2008) 
Deepak, V., Pandian, S.B.R.K., Kalishwaralal, K., Gurunathan, S.: Purification, immobilization and characterization of nattokinase on PHB nanoparticles. Bioresour. Technol. 100, 6644-6646 (2009)

Delvaux, M., Demoustier-Champagne, S.: Immobilisation of glucose oxidase within metallic nanotubes arrays for application to enzyme bionsensors. Biosens. Bioelectron. 18, 943-951 (2003)

DiCosimo, R., McAuliffe, J., Poulose, A.J., Bohlmann, G.: Industrial use of immobilized enzymes. Chem. Soc. Rev. 42, 6437-6474 (2013)

Erhardt, F.A., Jordening, H.J.: Immobilization of dextranase from Chaetomium erraticum. J. Biotechnol. 131, 440-447 (2007)

Falahati, M., Ma'mani, L., Sabuory, A.A., Shafiee, A., Foroumadi, A., Badiei, A.R.: Aminopropyl functionalized cubic Ia3d mesoporous silica nanoparticle as an efficient suport for immobilization of superoxide dismutase. Biochim. Biophys. Acta. 1814, 1195-1202 (2011)

Falahti, M., Saboury, A.A., Ma'mani, L., Shafiee, A., Rafieepour, H.A.: The effect of functionalization of mesoporous silica nanoparticles on the interaction and stability of confined enzyme. Int. J. Biol. Macromol. 50, 1048-1054 (2012)

Fargues, C., Bailly, M., Grevillot, G.: Adsorption of BSA and hemoglobin on hydroxyapatite support: equilibria and multicomponent dynamic. Adsorption 4, 5-16 (1998)

Fernandez-Lafuente, R.: Stabilization of multimeric enzymes: strategies to prevent subunit dissociation. Enzyme Microb. Technol. 45, 405-418 (2009)

Fornera, S., Bauer, T., Dieter Schluter, A., Walde, P.: Simple enzyme immobilization inside glass tubes for enzymatic cascade reactions. J. Mater. Chem. 22, 502-511 (2012)

Fransen, M.C.R., Steunenberg, P., Scott, E.L., Zuilhof, H., Sanders, J.P.M.: Immobilised enzymes in biorenewables production. Chem. Soc. Rev. 42, 6491-6533 (2013)

Garcia-Galan, C., Berenguer-Murcia, A., Fernandez-Lafuente, R., Rodrigues, R.C.: Potential of different enzyme immobilization strategies to improve enzyme performance. Adv. Synth. Catal. 353, 2885-2904 (2011)

Geng, L., Li, N., Xiang, M., Wen, X., Xu, D., Zhao, F., Li, K.: The covalent immobilization of trypsin at the galleries of layered $\gamma$ zirconium phosphate. Colloid Surf. B 30, 99-109 (2003)

Godjevargova, T., Nenkova, R., Konsulov, V.: Immobilization of glucose oxidase by acronitrile copolymer coated silica supports. J. Mol. Catal. B 38, 59-64 (2006)

Grabicka, B.E., Jaroniec, M.: Adsorption properties of ordered mesoporous silicas synthesized in the presence of block copolymer Pluronic F127 under microwave irradiation. Adsorption 16, 385-396 (2010)

Gray, C.J., Weissenborn, M.J., Eyers, C.E., Plitsch, S.L.: Enzymatic reactions on immobilised substrates. Chem. Soc. Rev. 42, 6378-6405 (2013)

Grudzień, R.M., Grabicka, B.E., Felix, R., Jaroniec, M.: Polymertemplated organosilicas with hexagonally ordered mesopores: the effect of organosilane addition at different synthesis stages. Adsorption 13, 323-329 (2007)

Grudzień, R.M., Grabicka, B.E., Jaroniec, M.: Adsorption and structural properties of channel-like and cage-like organosilicas. Adsorption 12, 293-308 (2006)

Gulec, H.A.: Immobilization of $\beta$-galactosidase from Kluyveromyces lactis onto polymeric membrane surfaces: effect of surface characteristics. Colloid Surf. B 104, 83-90 (2013)

Gupta, A., Prabhu, K.A.: Immobilization and properties of dextransucrase from Leuconostoc mesenteroides culture, $\mathrm{LM}_{1}$. J. Gen. Appl. Microbiol. 41, 399-407 (1995)

Gustafsson, H., Johansson, E.M., Barrabino, A., Oden, M., Holmberg, K.: Immobilization of lipase from Mucor miehei and Rhizopus oryzae onto mesoporus silca-the effect of varied particle size and morphology. Colloid Surf. B 100, 22-30 (2012)

Hanefeld, U., Cao, L., Magner, E.: Enzyme immobilisation: fundamentals and application. Chem. Soc. Rev. 42, 6211-6212 (2013)

Hanefeld, U., Gardosi, L., Magner, E.: Understanding enzyme immobilisation. Chem. Soc. Rev. 38, 453-468 (2009)

Hartmann, M., Kostrov, X.: Immobilization of enzymes on porous silicas-benefits and challenges. Chem. Soc. Rev. 42, 6277-6289 (2013)

Hartono, S.B., Qiao, S.Z., Liu, J., Jack, K., Ladewig, B.P., Hao, Z., Lu, G.Q.M.: Functionalized mesoporous silica with very large pores for cellulase immobilization. J. Phys. Chem. 83, 8353-8362 (2010)

Hernandez, K., Fernandez-Lafuente, R.: Control of protein immobilization: coupling immobilization and site-directed mutagenesis to improve biocatalyst or biosensor performance. Enzyme Microb. Technol. 48, 107-122 (2011)

Hita, E., Robles, A., Camacho, B., Gonzalez, P.A., Esteban, L., Jimenez, M.J., Munio, M.M., Molina, E.: Production of structured triacylglycerols by acidolysis catalyzed by lipases immobilized in a packed bed reactor. Biochem. Eng. J. 46, 257-264 (2009)

Honarkar, H., Barikani, M.: Applications of biopolymers. I. Chitosan. Monatsh Chem. 140, 1403-1420 (2009)

Hung, Y.J., Peng, C.C., Tzen, J.T.C., Chen, M.J., Liu, J.R.: Immobilization of Neocallimastix patriciarum xylanase on artificial oil bodies and statistical optimization of enzyme activity. Bioresour. Technol. 99, 8662-8666 (2008)

Hwang, E.T., Gu, M.B.: Enzyme stabilization by nano/microsized hybrid materials. Eng. Life Sci. 1, 49-61 (2013)

Iyer, P.V., Ananthanarayan, L.: Enzyme stability and stabilizationaqueous and non-aqueous environment. Process Biochem. 43, 1019-1032 (2008)

Jaroniec, M., Fulvio, P.F.: Standard nitrogen adsorption data for $\alpha$ alumina and their use for characterization of mesoporous alumina-based materials. Adsorption 19, 475-481 (2013)

Karboune, S., Neufeld, R., Kermasha, S.: Immobilization and biocatalysis of chlorophyllase in selected organic solvent systems. J. Biotech. 120, 273-283 (2005)

Karimpil, J.J., Melo, J.S., D’Souza, S.F.: Immobilization of lipase on cotton cloth using the layer-by-layer self-assemble technique. Int. J. Biol. Macromol. 50, 300-302 (2012)

Katchalski-Katzir, E., Kraemer, D.M.: Eupergit $\left.{ }^{(}\right)$C, a carrier for immobilization of enzymes of industrial potential. J. Mol. Catal. B 10, 157-176 (2000)

Kawaguti, H.Y., Hoffmann Carvalho, P., Figueira, J.A., Sato, H.H.: Immobilization of Erwinia sp. 12 cells in alginate-gelatin matrix and conversion of sucrose into osomaltulose using response surface methodology. Enzyme Res. 1, 1-8 (2011)

Kawakita, H., Sugita, K., Saito, K., Tamada, M., Sugo, T., Kawamoto, H.: Production of cycloisomaltooligosacharides from dextran using enzyme immobilized in multilayers porous membranes. Biotechnol. Prog. 18, 465-469 (2002)

Kennedy, L.J., Selvi, P.K., Padmanabhan, A., Hema, K.N., Sekaran, G.: Immobilization of polyphenol oxidase onto mesoporous activated carbons-isotherm and kinetic studies. Chemosphere 69, 262-270 (2007)

Klibanov, A.M.: Improving enzymes by using them in organic solvents. Nature 409, 241-246 (2001)

Kosaka, P.M., Kawano, Y., El Seound, O.A., Petri, D.F.S.: Catalytic activity of lipase immobilized onto ultrathin films of cellulose esters. Langmuir 23, 12167-12173 (2007)

Krajewska, B., Leszko, M., Zaborska, W.: Urease immobilized on chitosan membrane. Preparation and properties. J. Chem. Tech. Biotechnol. 48, 337-350 (1990) 
Krajewska, B., Zaborska, W., Leszko, M.: Inhibition of chitosanimmobilized urease by boric acid as determined by integration methods. J. Mol. Catal. B 3, 231-238 (1997)

Krajewska, B.: Application of chitin- and chitosan-based materials for enzyme immobilizations: a review. Enzyme Microb. Technol. 35, 126-139 (2004)

Krajewska, B.: Membrane-based processes performed with use of chitin/chitosan materials. Sep. Purif. Tech. 41, 305-312 (2005)

Krajewska, B., Zaborska, W.: Double mode of inhibition-inducing interactions of 1,4-naphthoquinone with urease. Arylation vs oxidation of enzyme thiols. Bioorg. Med. Chem. 15, 4144-4151 (2007)

Krajewska, B., Wydro, P., Jańczyk, A.: Probing the modes of antibacterial activity of chitosan. Effects of $\mathrm{pH}$ and molecular weight on chitosan interactions with membrane lipids in Langmuir films. Biomacromolecules 12, 4144-4152 (2011)

Krajewska, B., Wydro, P., Kyzioł, A.: Chitosan as a subphase disturbant of membrane lipid monolayers. The effect of temperature at varying pH: I. DPPG. Colloid Surf. A 434, 349-358 (2013a)

Krajewska, B., Kyzioł, A., Wydro, P.: Chitosan as a subphase disturbant of membrane lipid monolayers. The effect of temperature at varying pH: II. DPPC and cholesterol. Colloid Surf. A 434, 359-364 (2013b)

Krajewska, B.: Ureases I. Functional, catalytic and kinetic properties: a review. J. Mol. Cat. B 56, 9-21 (2009a)

Krajewska, B.: Ureases. II. Properties and their customizing by enzyme immobilizations: a review. J. Mol. Cat. B 59, 22-40 (2009b)

Krajewska, B., van Eldik, R., Brindell, M.: Temperature- and pressure-dependent stopped-flow kinetic studies of jack-bean urease. Implications for the catalytic mechanism. J. Biol. Inorg. Chem. 17, 1123-1134 (2012)

Kramer, M., Cruz, J.C., Pfromm, P.H., Rezac, E., Czermak, P.: Enantioselective transestrification by Candida antarctica lipase B immobilized on fumed silica. J. Biotechnol. 150, 80-86 (2010)

Kubac, D., Cejkova, A., Masak, J., Jirku, V., Lemaire, M., Gallienne, E., Bolte, J., Stloukal, R., Martinkova, L.: Biotransformation of nitriles by Rhodococcus equi A4 immobilized in LentiKats. J. Mol. Catal. B 39, 59-61 (2006)

Kumar, A., Kanwar, S.S.: Synthesis of ethyl ferulate in organic medium using celite-immobilized lipase. Bioresour. Technol. 102, 2162-2167 (2011)

Kwon, S.W., Jeong, B.O., Lee, E.H., Kim, Y.S., Jung, Y.: Conducting polimer silica composites for immoilization of enzymes. Bull. Korean Chem. Soc. 33, 1593-1596 (2012)

Labus, K., Gancarz, I., Bryjak, J.: Immobilization of laccase and tyrosinase on untreated and plasma-terated cellulosic and polyamide membranes. Mater. Sci. Eng. C 32, 228-235 (2012)

Lee, S.H., Doan, T.T.N., Won, K., Ha, S.H., Koo, Y.M.: Immobilization of lipase within carbon nanotube-silica composites for non-aqueous reaction systems. J. Mol. Catal. B 62, 169-172 (2010)

Liese, A., Hilterhaus, L.: Evaluation of immobilized enzymes for industrial applications. Chem. Soc. Rev. 42, 6236-6249 (2013)

Liu, C.H., Huang, C.C., Wang, Y.W., Lee, D.J., Chang, J.S.: Biodiesel production by enzymatic transestrification catalyzed Brukholderia lipase immobilized in hydrophobic magnetic particles. Appl. Energy 100, 41-46 (2012a)

Liu, N., Wang, Y., Zhao, Q., Cui, C., Fu, M., Zhao, M.: Immobilisation of lecitase ultra for producion of diacylglycerols by glycerolysis of soybean oil. Food Chem. 134, 301-307 (2012b)

Liu, Q., Kong, X., Zhang, C., Chen, Y., Hua, Y.: Immobilisation of a hydroperoxide lyase and comparative enzymological studies of the immobilised enzyme with membranę-bound enzyme. J. Sci. Food Agric. 93, 1953-1959 (2013)
Magner, E.: Immobilisation of enzymes on mesoporous silicate materials. Chem. Soc. Rev. 42, 6213-6222 (2013)

Mansur, H.S., Orefice, R.L., Lobato, Z.P., Vasconcelos, W.L., Mansur, E.S., Machado, L.J.C.: Adsorption/desorption behavior of bovine serum albumin and porcine insulin on chemically patterned porous gel networks. Adsorption 7, 105-116 (2001)

Marzadori, C., Miletti, S., Gessa, C., Ciurli, S.: Immobilization of jack bean urease on hydroxyapatite: urease immobilization on alkaline soils. Soil Biol. Biochem. 30, 1485-1490 (1998)

Mateo, C., Palomo, J.M., Fernandez-Lafuente, G., Guisan, J.M., Fernandez-Lafuente, R.: Improvement of enzyme activity, stability and selectivity via immobilization techniques. Enzyme Microb. Technol. 40, 1451-1463 (2007)

Mendes, A.A., Freitas, L., de Carvalho, A.K.F., de Oliviera, P.C., de Castro, H.F.: Immobilization of a commercial lipase from Penicillium camembertii (Lipase G) by different strategies. Enzyme Res. 2011, 1-8 (2011)

Mendes, A.A., Oliveira, P.C., Velez, A.M., Giordano, R.C., de Giordano, R.L.C., de Castro, H.F.: Valuation of immobilized lipases on poly-hydroxybutyrate beads to catalyze biodiesel synthesis. Int. J. Biol. Macromol. 50, 503-511 (2012)

Montiel, C., Terres, E., Dominguez, J.M., Aburto, J.: Immobilization of chloroperoxidase on silica-based materials for 4,6-dimethyl dibenzophene oxidation. J. Mol. Catal. B 48, 90-98 (2007)

Nara, T.Y., Togashi, H., Sekikawa, C., Inoh, K., Hisamatsu, K., Sakaguchi, K., Mizukami, F., Tsunoda, T.: Functional immobilizationof racemase by adsorption on folded-sheet mesoporous silica. J. Mol. Catal. B 64, 107-112 (2010)

Nasratun, M., Hasrul, A.S., Sureena, A., Nurul Aini, M.A., Ruwaida, A.R., Shalyda, M.S., Ideris, A., Rozaimi, A.S., Sharifuddin, J.H., Ahamad Nordin, N.I.A.: Immobilization of lipase from Candida rugosa on chitosan beads for transesterification reaction. J. Appl. Sci. 10, 2701-2709 (2010)

Nwagu, T.N., Okolo, B.N., Aoyagi, H.: Immobilization of raw starch digesting amylase on silica gel: a comparative study. Afr. J. Biotechnol. 10, 15989-15997 (2011)

Ozturk, T.K., Kilinc, A.: Immobilization of lipase in organic solvent in the presence of fatty acid additives. J. Mol. Catal. B 67, 214-218 (2010)

Pesic, M., Lopez, C., Alvaro, G., Lopez-Santin, J.: A novel immobilized chloroperoxidase biocatalyst with improved stability for the oxidation of amino alcohols to amino aldehydes. J. Mol. Catal. B 84, 144-151 (2012)

Rekuć, A., Bryjak, J., Szymańska, K., Jarzębski, A.B.: Very stable silica-gel-bound laccase biocatalysts for the selective oxidation in continuous systems. Bioresour. Technol. 101, 2076-2083 (2010)

Reshmi, R., Sanjay, G., Sugunan, S.: Enhanced activity and stability of $\alpha$-amylase immobilized on alumina. Catal. Commun. 7, 460-465 (2006)

Reshmi, R., Sanjay, G., Sugunan, S.: Immobilization of $\alpha$-amylase on zirconia: a heterogeneous biocatalyst for starch hydrolysis. Catal. Commun. 8, 393-399 (2007)

Rodrigues, R.C., Ortiz, C., Berenguer-Murcia, A., Torres, R., Fernandez-Lafuente, R.: Modifying enzyme activity and selectivity by immobilization. Chem. Soc. Rev. 42, 6290-6307 (2013)

Rodrigues, R.C., Berenguer-Murcia, A., Fernandez-Lafuente, R.: Coupling chemical modification and immobilization to improve the catalytic performance of enzymes. Adv. Synth. Catal. 353, 2216-2238 (2011)

Sakai, S., Liu, Y., Yamaguchi, T., Watanabe, R., Kawabe, M., Kawakami, K.: Production of butyl-biodiesel using lipase physically-adsorbed onto electrospun polyacrylonitryle fibers. Bioresour. Technol. 101, 7344-7349 (2010)

Salis, A., Casula, M.F., Bhattacharyya, M.S., Pinna, M., Solinas, V., Monduzzi, M.: Physical and chemical lipase adsorption on SBA- 
15: effect of different interactions on enzyme loading and catalytic performance. Chem. Cat. Chem. 2, 322-329 (2010)

Santos, J.C., Nunes, G.F.M., Moreira, A.B.R., Perez, V.H., de Castro, H.F.: Characterization of Candida rugosa lipase immobilized on poly(N-methyloacrylamide) and its application in butyl butyrate synthesis. Chem. Eng. Technol. 30, 1255-1261 (2007)

Sheldon, R.A., van Pelt, S.: Enzyme immobilisation in biocatalysis: why, what and how? Chem. Soc. Rev. 42, 6223-6225 (2013)

Sheldon, R.A.: Enzyme immobilization: the quest for optimum performance. Adv. Synth. Catal. 49, 1289-1307 (2007)

Spinelli, D., Fatarella, E., Di Michele, A., Pogni, R.: Immobilization of fungal (Trametes versicolor) laccase onto Amberlite IR-120 H beads: optimization and characterization. Proc. Biochem. 48, 218-223 (2012)

Tavares, A.P.M., Rodriguea, O., Fernandez-Fernandez, M., Dominguez, A., Moldes, D., Sanroman, M.A., Macado, E.A.: Immobilization of laccase on modified silica: stabilization, thermal inactivation and kinetic bahaviour in 1-ethyl-3-methylimidazolium ethylsulfate inonic liquid. Bioresour. Technol. 131, 405-412 (2013)

Thorn, C., Gustafsson, H., Olsson, L.: Immobilization of feruloyl esterases in mesoporous materials leads to improved transestrification yield. J. Mol. Catal. B 72, 57-64 (2011)

Thudi, L., Jasti, L.S., Swarnalahta, Y., Fadnavis, N.W., Mulani, K., Deokar, S., Ponratham, S.: Enzyme immobilization on epoxy supports in reverse micellar media: prevention of enzyme denaturation. J. Mol. Catal. B 74, 54-62 (2012)

Torres, P., Reyes-Duarte, D., Lopez-Cortes, N., Ferrer, M., Ballesteros, A., Plou, F.J.: Acetylation of vitamin E by Candida antarctica lipase B immobilized on diffrent carriers. Proc. Biochem. 43, 145-153 (2008)

Tran, D.T., Chen, C.L., Chang, J.S.: Immobilization of Brukholderia sp. lipase on a ferric nanocomposite for biodiesel production. J. Biotech. 158, 112-119 (2012)

Tuzmen, N., Kalburcu, T., Denizli, A.: Immobilization of catalase via adsorption onto metal-chelated affinity cryogels. Proc. Biochem. 47, 26-33 (2012)

Vinoba, M., Bhagiyalakshmi, M., Jeong, S.K., Yoon, Y.I., Nam, S.C.: Immobilization of carbonic anhydrase on spherical SBA-15 for hydration and sequestration of $\mathrm{CO}_{2}$. Colloid Surf. B 90, 91-96 (2012)

Wang, S., Su, P., Ding, F., Yang, Y.: Immobilization of cellulase on polyamidoamine dendrimer-grafted silica. J. Mol. Catal. B 89, 35-40 (2013)

Wanjari, S., Pabhu, C., Satyanarayana, T., Vinu, A., Rayalu, S.: Immobilization of carbonic anhydrase on mesoporous aluminosilicate for carbonation reaction. Micropor. Mesopor. Mater. 160, 151-158 (2012)

Weber, E., Sirim, D., Schreiber, T., Thomas, B., Pleiss, J., Hunger, M., Glaser, R., Urlacher, V.B.: Immobilization of P450 BM-3 monooxygenase on mesoporous molecular sives with different pore diameters. J. Mol. Catal. B 64, 29-37 (2010)

Wu, C., Zhou, G., Jiang, X., Ma, J., Zhang, H., Song, H.: Active biocatalysts based on Candida rugosa lipase immobilized in versicular silica. Proc. Biochem. 47, 953-959 (2012)

Wu, H., Wang, J., Kang, X., Wang, C., Wang, D., Liu, J., Aksay, I.A., Lin, Y.: Glucose biosensor based on immobilization of glucose oxidase in pltinum nanoparticles/graphene/chitosan nanocomposite film. Talanta 80, 403-406 (2009)
Xiao, P., Lv, X., Deng, Y.: Immobilization of chymotrypsin on silica beads based on high affinity and specificity aptamer and its applications. Anal. Lett. 45, 1264-1273 (2012)

Xie, W., Wang, J.: Immobilized lipase on magnetic chitosan microspheres for transestrification of soybean oil. Biomass Bioenergy 36, 373-380 (2012)

Xu, F., Wang, W.H., Tan, Y.J., Bruening, M.L.: Facile trypsin immobilization in polymeric membranes for rapid, efficient, protein digestion. Anal. Chem. 82, 10045-10051 (2010)

Yang, J., Hu, Y., Jiang, L., Zou, B., Jia, R., Huang, H.: Enhancing the catalytic properties of porcine pancreatic lipase by immobilization on SBA-15 modified by functionalized ionic liquid. Biochem. Eng. J. 70, 46-54 (2013)

$\mathrm{Yu}$, J., Ju, H.: Preparation of porous titania sol-gel matrix for immobilization of horseradish peroxidase by a vapor deposition method. Anal. Chem. 74, 3579-3583 (2002)

Yu, W., Fang, M., Tong, D.S., Shao, P., Xu, T., Zhou, C.: Immobilization of Candida rugosa lipase on hexagonal mesoporous silca and selective estrification in nonaqueous medium. Biochem. Eng. J. 70, 97-105 (2013)

Yucel, Y.: Optimization of immobilization conditions of Thermomyces lanuginosus lipase on olive pomace powder using response methodology. Biocatal. Agric. Biotechnol. 1, 39-44 (2012)

Zaidan, U.H., Rahman, M.B.A., Othman, S.S., Basr, M., Abdulmalek, E., Rahman, R.N.Z.R.A., Salleh, A.B.: Biocatalytic production of lactose ester catalysed by mica-based immobilised lipase. Food Chem. 131, 199-205 (2012)

Zhai, R., Zhang, B., Liu, L., Xie, Y., Zhang, H., Liu, J.: Immobilization of enzyme biocatalyst on natural halloysite nanotubes. Catal. Commun. 12, 259-263 (2010)

Zhang, B., Xing, J.M., Liu, H.Z.: Synthesis and characterization of superparamagnetic poly(urea-formaldehyde) adsorbents and their use for adsorption of flavonoids from Glycyrrhiza uralensis Fisch. Adsorption 14, 65-72 (2008)

Zhang, Y.T., Zhi, T.T., Zhang, L., Huang, H., Chen, H.L.: Immobiliation of carbonic anhydrase by embedding and covalent coupling into nanocomposite hydrogel containig hydrotalcite. Polymer 50, 5693-5700 (2009)

Zhao, H.: Methods for stabilizing and activating enzymes in ionic liquids: a review. J. Chem. Technol. Biotechnol. 85, 891-907 (2010)

Zheng, M.M., Lu, Y., Dong, L., Guo, P.M., Deng, Q.C., Li, W.L., Feng, Y.Q., Huang, F.H.: Immobilization of Candida rugosa lipase on hydrophobic/strong cation-exchange functional silica particles for biocatalytic synthesis of phytosterol esters. Bioresour. Technol. 115, 141-146 (2012)

Zhou, G., Fung, K.K., Wong, L.W., Chen, Y., Renneberg, R., Yang, S.: Immobilization of glucose oxidase on rod-like and vesiclelike mesoporous silica for enhancing current responses of glucose biosensors. Talanta 84, 659-665 (2011)

Zhu, H., Pan, J., Hu, B., Yu, H.L., Xu, J.H.: Immobilization of glycolate oxidase from Medicago falcata on magnetic nanoparticles for applications in biosynthesis of glyoxylic acid. J. Mol. Catal. B 61, 174-179 (2009)

Zhu, Y., Kaskel, S., Shi, J., Wage, T., Van Pee, K.H.: Immobilization of Tramtes versicolor laccase on magnetically separable mesoporous silica spheres. Chem. Mater. 19, 6408-6413 (2007) 